\title{
Assessment of energy-efficient appliances: A review of the technologies and policies in India's residential sector
}

\author{
Vivek Kumar Singh ${ }^{1,2}$ (1) | Carla Oliveira Henriques ${ }^{2,3,4}$ | António Gomes Martins 2,4,5 $^{2,4}$
}

${ }^{1}$ MIT-Portugal Program, University of Coimbra, Coimbra, Portugal

${ }^{2}$ Energy for Sustainability Initiative, University of Coimbra, Coimbra, Portugal

${ }^{3}$ Polytechnic Institute of Coimbra, Coimbra Business School ISCAC, Coimbra, Portugal

${ }^{4}$ INESC Coimbra, Coimbra, Portugal

${ }^{5}$ Department of Electrical Engineering and Computers, University of Coimbra, Coimbra, Portugal

Correspondence

Vivek Kumar Singh, Energy for Sustainability Initiative, MIT-Portugal Program, University of Coimbra, Coimbra, Portugal.

Email: vivekkumarsingh22@gmail.com

Funding information

Portuguese Foundation for Science and Technology (FCT), Grant/Award Number: UID/ MULTI/00308/2013; MIT-Portugal Program; FCT/Portugal, Grant/Award Number: SFRH/ $\mathrm{BD} / 52308 / 2013$
The promotion of energy efficiency has been at the forefront of the energy policy agenda. New technological inventions and increasing environmental concerns related to contemporary energy policy are the main drivers of the adoption of more energy-efficient appliances in domestic sector. Additionally, the mandatory star labeling program and incentive design mechanisms are also raising awareness and motivation for their use, thus contributing to the reduction of energy consumption and greenhouse gas emissions. Sustainable energy policies generally pursue programs aiming for energy efficiency among domestic appliances. In India there are currently nine domestic electrical appliances/end-uses certified with star labeling programs, in particular lighting sources, refrigerators, air conditioners, water heaters, televisions, computers, washing machines, ceiling fans, and water pumps. This study reviews main issues affecting selection of energy-efficient technologies in India's domestic sector highlighting the main challenges impacting design of energy efficiency policies and programs in the country.

This article is categorized under:

Energy and Climate $>$ Economics and Policy

Energy Efficiency $>$ Economics and Policy

Energy and Development $>$ Systems and Infrastructure

\section{KEYWORDS}

appliances, energy consumption, energy efficiency, market transformation, standards and labeling

\section{I INTRODUCTION}

Energy performance on a global scale depends on several factors such as energy supply, energy demand, and market transformation (MT) (Jefferson, 2016). Therefore, the implementation of energy efficiency measures (EEM) in commercial and residential sectors plays a prominent role in the reduction of energy demand, further contributing to reduce global warming (Sorrell, 2015). According to an International Energy Agency (IEA) report, 71\% of the world greenhouse gas (GHG) emission reduction would come from energy efficiency improvements by 2020 and 38\% by 2050 (Ryan \& Campbell, 2012). Energy efficiency is recognized as a key strategy to tackle three energy-related challenges-climate change, energy security, and economic development—at the least cost to society (Bukarica \& Tomšić, 2017). Additionally, the policies promoting energy efficiency in the household sector are significantly and positively related to energy-efficient innovations introduced in the building sector and lighting technologies, particularly among the developing countries of the Asia-Pacific region (Girod, Stucki, \& Woerter, 2017). Furthermore, developing countries face critical energy security issues due to their fast economic growth inherently supported by an increasing demand for energy (Rasul \& Sharma, 2016). In fact, in 2014, India's domestic 
sectors consumed about $45 \%$ of primary energy (TERI, 2014). In the domestic sector, energy is primarily used for electrical equipment/appliances, lighting, and cooking, (Drysdale, Wu, \& Jenkins, 2015).

The first studies aimed at estimating the potential energy savings obtainable with the use of more efficient refrigerators and air conditioning systems in India's households were published by (CMIE, 2000; Letschert, McNeil, Zhou, \& Sathaye, 2009; Murthy, Sumithra, \& Reddy, 2001; TERI, 2006). The Lawrence Berkeley National Laboratory (LBNL) also published a report on the assessment of the potential energy efficiency improvements of India's residential sector. However, the type of analysis therein presented accounted for the energy savings potential in the residential sector as a whole rather than per appliance or end-use. In another study conducted by the LBNL projections were issued regarding the required energy efficiency improvements in India's residential sector to cope with the residential electricity demand in the future (Mundaca, Neij, Worrell, \& McNeil, 2010). The World Bank (2008) estimated the ownership rate of various electrical appliances in India's residential sector based on the projected income. In a study prepared by the LBNL, several strategies were also discussed for attaining low carbon growth in India's industry and nonresidential sectors. Since then, few publications arose in the scientific literature trying to estimate ownership rates for selected appliances, particularly addressing air conditioner systems (McNeil, Iyer, Meyers, Letschert, \& McMahon, 2008), electric fans, television (TV), and refrigerators (Rathi, Chunekar, \& Kadav, 2012).

More recently, the India's Low Carbon Strategy for Inclusive Growth highlights the importance of the potential energy savings achievable with the use of energy-efficient appliances (Planning Commission Government of India, 2014). According to the Standards and Labeling (S\&L) scheme recognized by the Bureau of Energy Efficiency (BEE) of the Government of India there are 10 of 21 types of star-rated appliances used in households.

In an environment of rapid economic growth with high urbanization rates, the growing India's middle class pursues higher comfort levels through the purchase of a large number of appliances (Bhattacharyya, 2014). Therefore, the consequent rise in energy consumption and GHG emissions can be significantly mitigated if consumers are motivated and made aware of the different options that the market has to offer regarding the panoply of energy-efficient technologies (EET) available (Parikh \& Parikh, 2016).

In this context, this study provides an updated and systematic review which aims at contributing to the discussion of the main challenges ahead regarding the design of energy efficiency policies in India. In Section 2, a brief overview of the current energy consumption patterns in India will be presented. Section 3 provides a brief overview of the technological characteristics of the appliances/end-uses typically used in India's residential sector. Section 4 describes the specific features of these appliances and end-uses. Section 5 reviews some dimensions of the energy efficiency governance framework in India. Section 6 discusses the most important cobenefits associated to the use of energy-efficient appliances. Section 7 addresses the MT overarching framework regarding energy efficiency. Section 8 is foremost dedicated to the energy efficiency market barriers. Finally, some conclusions are drawn that can contribute to the discussion and design of energy efficiency policies and programs in India.

\section{2 | ELECTRICITY CONSUMPTION PATTERNS IN INDIA}

Energy is the basic building block of economic development (Ghosh, 2002). Energy consumption plays an important role in growth and development processes as it facilitates production and improves household welfare (Karekezi, 2002). Final energy consumption is usually allocated to three main activity sectors: industry, transport, and "others"-including agriculture, services, and the residential sector (Pérez-Lombard, Ortiz, \& Pout, 2008). The share of the residential sector electricity consumption in India reached about 24\% in 2016-2017 (Central Electricity Authority [CEA], 2017). Therefore, after industry, which accounts for $40.1 \%$ of the total electricity consumed in India, the residential sector is the second biggest energy consumer. Figure 1 highlights the contrasting electricity consumption patterns in different sectors from 2011 to 2017 (CEA, 2017). Electricity consumption in the residential sector has been increasing $2.20 \%$ per year while in the industrial sector it has been decreasing about $2.24 \%$ over the last 5 years.

In 2014, the countries with the highest share of electricity consumption in the residential sector were the United States (36.88\%), France (36.46\%), and the United Kingdom (36.12\%) - Table 1. In developed countries, the energy consumption shares in the residential sector reach 20-37\% of the total energy use while in BRICS (Brazil, Russia, India, China, and South Africa) these values range between 15 and 25\% of total electricity consumption in the residential sector (Ministry of Power, 2015).

\section{3 | TECHNOLOGICAL CHARACTERISTICS OF APPLIANCES/END-USES}

India is rapidly transforming into an urban country, but small towns and farming communities still make up the clear majority of its population. A government's survey shows that the spending patterns of India's population in cities and villages are fast converging, as rural households now pay for most goods and services usually associated with urban lifestyles (Malik, 2016). 


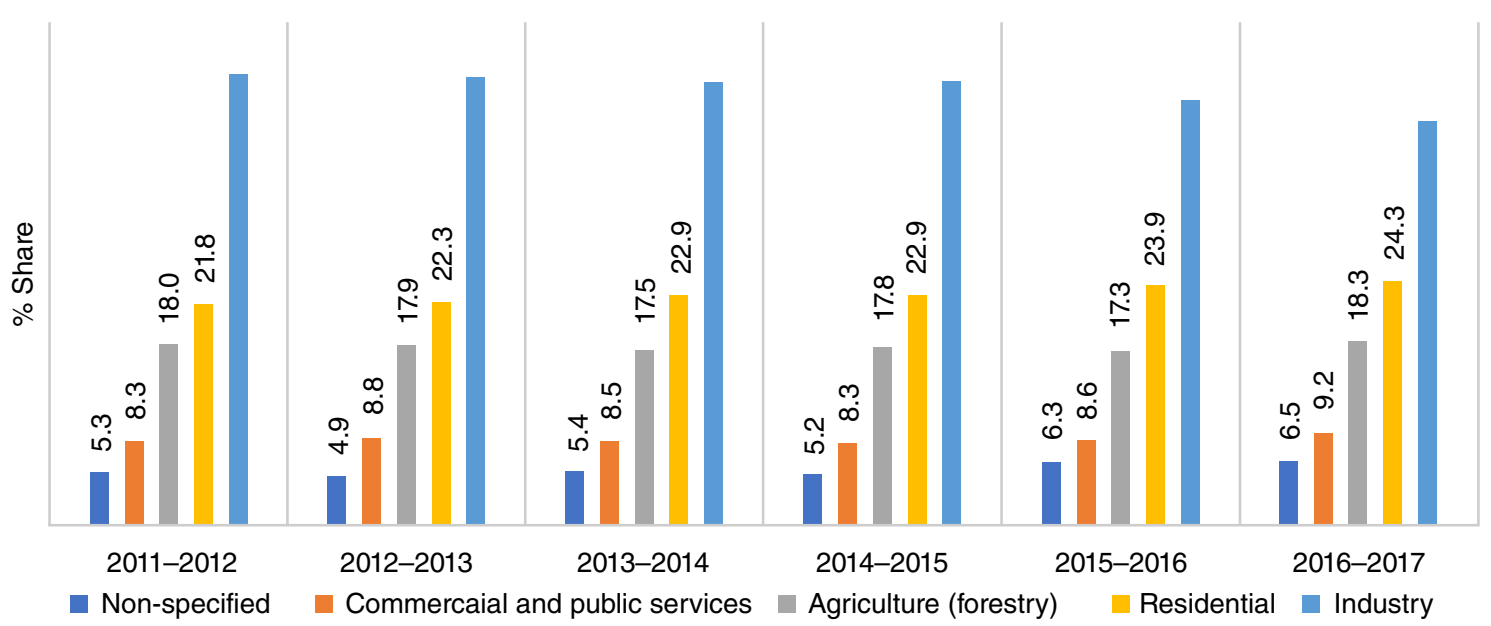

FIGURE 1 Share of electricity consumption by activity sectors from 2011 to 2017 in India

The steady increase of technological innovation has had significant repercussions on the electrical appliances available on the market. In order to promote the reduction of energy consumption of appliances in the residential sector it is necessary to foster the investment on highly efficient appliances (Goetzler, Sutherland, \& Foley, 2014). In the next subsections, we present a thorough description of the main end-use appliances that may be found in India's residential sector.

\section{1 | Room air conditioners}

Room or window air conditioners cool limited areas rather than the complete building. If cooling is provided only where it is needed, room air conditioners (RACs) are less expensive to operate than central units, despite the fact that their efficiency is generally lower than that of central air conditioners (RAC, 2016). The businesses and residences of India use both windowmounted and split air-conditioning units. Historically, window units have conquered the market, and most of air conditioners were sold to businesses. Since 2008, the BEE presented a plan for progressively improving the efficiency of room air conditioning and promoting the MT toward better energy efficiency standards. In 2016, the S\&L program has had a positive impact on the market penetration of energy-efficient air conditioners, with the sales of five star-rated systems reaching a share of $34 \%$ (Sundarmoorthy \& Walia, 2017). Finally, it is worth mentioning that the BEE has also adjusted the standards for certifying the star-rating of these devices in such a way that the five star label rating obtained in 2010 became only three star label rating in 2015 and will become one star in 2018 according to the new India's Seasonal Energy Efficiency Ratio (ISEER) methodology (Ministry of Power, 2016).

TABLE 1 Electricity consumption per country in 2014

\begin{tabular}{|c|c|c|c|c|c|c|}
\hline Country & Nonspecified, \% & Agriculture (forestry), \% & $\begin{array}{l}\text { Commercial and } \\
\text { public services, \% }\end{array}$ & Residential, \% & Transportation, $\%$ & Industry, \% \\
\hline Australia & 0 & 1.11 & 29.11 & 29.64 & 1.95 & 38.20 \\
\hline Canada & 0 & 1.82 & 29.49 & 30.49 & 0.84 & 37.36 \\
\hline France & 0.36 & 1.84 & 32.11 & 36.46 & 2.86 & 26.34 \\
\hline Germany & 0 & 0 & 28.62 & 26.05 & 2.30 & 43.02 \\
\hline Italy & 0 & 1.96 & 30.42 & 23.41 & 3.63 & 40.55 \\
\hline Japan & 0.75 & 0.10 & 36.10 & 31.14 & 2.02 & 29.90 \\
\hline Korea & 0 & 1.99 & 31.69 & 13.27 & 0.47 & 52.06 \\
\hline United Kingdom & 0 & 1.22 & 30.57 & 36.12 & 1.29 & 30.8 \\
\hline United States & 3.89 & 0.83 & 35.52 & 36.88 & 0.18 & 22.7 \\
\hline South Africa & 1.69 & 2.90 & 14.30 & 19.68 & 1.94 & 59.5 \\
\hline Brazil & 0 & 4.92 & 25.29 & 24.88 & 0.59 & 44.32 \\
\hline Republic of China & 7.63 & 2.45 & 5.92 & 15.06 & 1.26 & 67.68 \\
\hline Russian Federation & 0 & 2.06 & 21.87 & 17.86 & 12.43 & 45.74 \\
\hline European Union-27 & 0.30 & 1.58 & 30.21 & 29.62 & 2.29 & 35.98 \\
\hline India (2014-2015) & 5.20 & 17.81 & 8.26 & 22.92 & 1.71 & 44.11 \\
\hline World & 4.07 & 2.84 & 22.06 & 26.99 & 1.53 & 42.52 \\
\hline
\end{tabular}




\section{2 | Ceiling fans}

Ceiling fans (CF) are the most common electrical appliances after electric lighting in India's households and offices, and nevertheless, they have been rarely mentioned in the discussions of energy efficiency concerns (Singh, Sant, \& Chunekar, 2010). In 2017, CF consumed about $20 \%$ of the electricity in India's households, and their numbers are increasing rapidly (Balasubramanian, 2017). The production of CF in India is about 40 million units per year, which, in 2010 (the most recent data known to the authors), corresponded to 28 million units in terms of annual sales just for India (Singh et al., 2010).The Bureau of Indian Standards (BIS) is responsible for specifying the minimum performance requirements for CF. Most of the chief brands also have energy saving models which consume at around $35 \mathrm{~W}$ (Balasubramanian, 2017). In 2016, the positive impacts of the S\&L program can be seen in the sales of CF, which corresponded to nearly $100 \%$ of five star products (Sundarmoorthy \& Walia, 2017).

\section{3 | Lighting}

In 2015 , lighting was also a major energy consumer, representing roughly $20 \%$ of electricity consumption in India (IEA, 2015). There is a significant technical potential to reduce energy consumption from electric lighting with high efficient lamps, light control systems, and improved building designs (IEA, 2013). Much higher improvements are possible with gas discharge lamps, typically fluorescent lamps (FL), and with solid-state light-emitting diode (LED). FL are low-pressure gas discharge light sources, producing light mainly by fluorescent powders which get activated by ultraviolet radiation created by discharges in mercury (Halonen, Tetri, \& Bhusal, 2010). The lighting appliance stock data from Electric Lamp and Component Manufacturers Association of India (ELCOMA) estimated that, in 2014, there were about 780 million incandescent bulbs (IL), 234 million FL, and 453 million compact FL (CFL) (ELCOMA, 2014).

In the building sector, both tubular fluorescent lamp (TFL) and CFL are the most commonly used lighting sources, with the latter gaining an increased popularity due to a sharp price drop in the past and to its similarity with IL (Mandil, 2006). Over the last decades, many governments have passed measures to replace conventional IL with CFL, as they only require around one-quarter to one-third of electricity to produce the same amount of visible light (IEA, 2013). Additionally, although LED lighting technology only represented 1\% of the market share in 2013 it represented 70\% in 2017 (ELCOMA, 2017). In fact, LED lighting technology may lead to 75\% of energy savings (National Electrical Manufacturers Association (USA) [NEMA], 2014) and longer life spans than IL (Nardelli, Deuschle, de Azevedo, Pessoa, \& Ghisi, 2017). Nevertheless, a major market barrier for CFL and LED is their higher initial costs in comparison to IL, although they are normally more economical on a life cycle basis, because of their lower energy consumption and longer lifetimes (Lefèvre, De T'serclaes, \& Waide, 2006). Other market barriers are lack of consumer awareness and distrust of consumers in the technology, as CFL had at the beginning of its commercialization some quality and suitability issues to overcome (Letschert, Bojda, Ke, Mcneil, \& Lawrence, 2012).

\section{4 | Refrigeration}

Refrigeration appliances can be categorized into four groups: refrigerator/freezer combinations, refrigerators only, refrigerators with freezer compartments, and freezers only (Letschert et al., 2012). The technologies across the different categories have very similar operation modes, which are typically based on an electrically driven vapor compression refrigeration cycle (BijliBachao, 2017). There are two main product groups for residential refrigerators in India: single-door direct cool (manual defrost) and two-door frost-free. Traditionally, direct cool units have taken over the market, but frost-free units are gaining importance. Several low-cost technologies for refrigeration appliances are available to improve their energy efficiency. The LBNL assessed a cost-effective approach for accomplishing the reduction of energy consumption in this type of electrical devices from 4 to $71 \%$ through the enhancement of its design just by including thicker insulation, increasing the surface area of evaporators and condensers, and incorporating higher efficiency compressors, thermostatic controls, vacuum insulation pumps (VIP), and optimized capillary tube characteristics (Letschert et al., 2012; Shah, Park, Bojda, McNeil, \& Waide, 2014). In 2016, the sales of 5-star refrigeration appliances in India had a share of 25\%, while the 4-star represented 10\%, the 1- and 2 -star corresponded to $18 \%$ and the 3 -star attained $29 \%$, respectively (Sundarmoorthy \& Walia, 2017).

\section{5 | Televisions}

A rapid improvement of energy efficiency in TV happened in the last decade (e.g., cathode-ray tube [CRT] to liquid crystal display [LCD] and cold-cathode FL backlit LCD [CCFL-LCD] to LED backlit LCD [LED-LCD]), although simultaneously with an expected increase of penetration in households, especially in emerging economies, as well as the anticipated increase of the average screen size of the TV sets purchased (Park, Phadke, Shah, \& Letschert, 2011). The market transition regards 
the replacement of cold CCFL backlit LCD TV with higher efficient LED backlit LCD TV. The well-known progressive shift from analogue to digital TV as well as the improvement of energy efficiency standards increased world-wide (Park et al., 2011). Plasma TV have a small portion of sales and are mainly present in the market for large screen sizes (Chunekar \& Singh, 2013). Screen sizes and time of use have considerable impacts on annual electricity consumption. For instance, a growth in the diagonal's screen size of $40 \%$ leads to a $60 \%$ increase in electricity consumption (IEA, 2010a). In 2016, the share of 2-star TV sales in India was 55\%, while 4- and 3-star corresponded to a share of 20\% and only 5\% were attained for 1-star TV sales (Sundarmoorthy \& Walia, 2017).

\section{6 | Water heaters}

Water heaters are major energy consumers both in the residential and the commercial sectors. Conventional storage water heaters and instantaneous water heaters remain the most popular types of water heating systems for homes and buildings (Department of Energy, 2017). A storage water heater operates by releasing hot water from the top of the tank when a hot water tap is turned on. To replace that hot water, cold water enters the bottom of the tank, ensuring that the tank is always full (IEA, 2013). However, instantaneous water heaters produce hot water on demand using a gas burner or electric heating coil. Thus, instantaneous water heaters tend to have higher energy efficiencies by eliminating standby heat losses associated with a tank and often substantially reducing pipe losses (Maguire, Fang, \& Wilson, 2013). Gas water heaters have normally lower rated energy efficiencies than electric ones, due to the combustion efficiency of gas and higher tank losses. However, these can represent an overall higher energy efficiency considering the energy source used, since there are no intermediary energy conversions to electricity when gas is directly burned to obtain heat. Condensing water heaters improve the energy efficiency of storage and instantaneous gas water heaters by about 10-30\% capturing the latent heat of the combustion gas before it exits (Lekov, Franco, Wong-Parodi, McMahon, \& Chan, 2010).

In India, the BEE labeling scheme for this sort of equipment has been in place for several years and it was voluntary until July 2015 (AEEE, 2015). Currently, however, there are mandatory labels for storage electric water heaters which consider a star rating system based on the standing (heat/energy) losses $\left(\mathrm{kWh} / 24 \mathrm{hr} / 45^{\circ} \mathrm{C}\right.$ difference) calculated according to IS 2082:1993. In this context, water heaters are categorized in 10 different rated capacities ranging from 6 to $200 \mathrm{~L}$ (Collaborative Labelling and Appliance Standards Program [CLASP], 2015).

\section{7 | Electric water pump motors}

In India, pumps are used in the domestic, industrial, and agriculture sectors. India's agriculture sector is the largest user of pumps, for several applications such as irrigation and water distribution; in the industrial and domestic sectors, pumps are used for water supply, sewage, and chemical supply.

The BEE has included the electric water pump sets in the voluntary labeling scheme. Most of the national manufacturers consider the star labeling program is an appropriate approach to save electricity (Engineerlive, 2013). A study by Shakti Foundation has shown that the market shares of pumps by end-users, are 30\% for domestic, 35\% for industrial, and 35\% for the agriculture sector with an estimated total motor manufacturing growth of 22\% between 2009 and 2014 (SSEF, 2012). India's household water pumps lie between a rated output of 0.37-2.2 kW (Padmavathi \& Daniel, 2011). The star labeling rating of electric motors by the BEE is categorized in accordance with the International Electrotechnical Commission (IEC) standards. The motors lie between the ranges of IE1 and IE3 standard with an operating efficiency of 69-90\% for all 2-pole, 4-, and 6pole motors. Around one-third of the energy savings potential for electric motors is observed in motors ranging from 0.75 to $4 \mathrm{~kW}$ (U.S. Department of Energy, 2013). IEC has concentrated on single-speed, three-phase, 50 and $60 \mathrm{~Hz}$ AC squirrel-cage induction motors in the range $0.75-375 \mathrm{~kW}$ in its published standard IEC 60034-30:2008 and reviewed by IEC 60034-30-1:2014 (AAB, 2014).

\section{8 | Computers}

The Environmental Protection Agency (EPA) started a system of energy star rating in July of 2009 to classify computers, laptops, and tablets based on their yearly electricity consumption (Energy Star, 2009). The standards were set so that only $25 \%$ of the most efficient computers made the cut. This made sure that the energy star classified computers were $30 \%$ more efficient than the nonclassified ones. The Computer Specification, version 5.0 (2009), classification suggested by EPA is given below: Category A: $\leq 148.0 \mathrm{kWh}$; Category B: $\leq 175.0 \mathrm{kWh}$; Category C: $\leq 209.0 \mathrm{kWh}$; and Category D: $\leq 234.0 \mathrm{kWh}$. The BEE has extended the application of this energy star rating system to India for computers and laptops (Bijli Bachao, 2016). 


\section{9 | Washing machines}

Although not mandatory, the BEE always recommends the purchase of 5-star-rated washing machine (WM) devices. The BEE labeling system of energy-efficient WM depends on the size and front load or top load and water efficiency (Cleaning Institute, 2010). WM in India are broadly classified into two categories: semi-automatic and fully automatic. WM with a lower capacity range from 5 to $9 \mathrm{~kg}$. However, the capacity of fully automatic WM varies from 6 to $11 \mathrm{~kg}$, going up to $17 \mathrm{~kg}$ in some brands (Aggarwal \& Singh Rana, 2016).

\section{I SPECIFIC FEATURES OF APPLIANCES/END-USES}

Over the last two decades, the ownership rate of electrical appliances has increased substantially both in rural and urban households due to the rise of the income level (NITI Aayog, 2016; Thomas, Tholen, Rasch, \& Hafiz, 2015). The market of electronic appliances in India has been growing consistently mainly due to affordable prices, constant technological innovations and intense competition.

In the next subsections, the distinct features of each appliance under consideration will be presented.

\section{1 | Lifetime}

The lifetime mainly depends on the operating hours (e.g., TFL usually are assumed to last 20,000 hr, under the assumption of daily use of $4 \mathrm{hr}$, which corresponds to an average lifetime of 14 years). In spite of longer lifetimes achieved by technological advancements, these are being overshadowed by fast consumption trends (Cravioto, Yasunaga, \& Yamasue, 2017). The lifetime also depends on the consumption behaviors and on the socioeconomic characteristics of households (e.g., a household with many members will have a more intensive use of a WM) (Matsumoto, 2016). Table 2 presents the average lifetime of several appliances typically used in India's households.

\section{2 | Operating time}

India can be divided into five different climatic regions, that is, hot and dry, warm and humid, composite, temperate, and cold (BEE, 2007). Hence, the operating time of appliances differs according to each climatic region. The operating time is usually calculated based on the power of the devices $(W)$, on the frequency of use, and on the average regional climatic conditions and average working days (e.g., on average, CF are used $8 \mathrm{hr} /$ day and for about 200 days/year). Table 3 depicts the operating time of the main appliances typically used in India's households based on available literature (Boegle et al., 2007; TERI, 2006; World Bank, 2008). The discrepancy of data presented in Table 3 regarding the appliances' operating time can be attributed to several differences among the targets of the reported studies, namely the family size, the geographical regions as well as differences between rural and urban households.

\section{I AN OVERVIEW OF ENERGY EFFICIENCY GOVERNANCE IN INDIA}

According to IEA (2010b), "Energy efficiency governance is the combination of legislative frameworks and funding mechanisms, institutional arrangements, and coordination mechanisms, which work together to support implementation of energy efficiency strategies, policies, and programmes." Therefore, energy efficiency governance should cover a broad set of aspects

TABLE 2 Lifetime of the main appliances typically used in India's households

\begin{tabular}{lcl}
\hline Appliance/End-use & Lifetime in years & References \\
\hline TFL & $14^{\mathrm{a}}$ & ATD Homeinspection (2010) \\
\hline EG & 15 & Department of Energy (2017) \\
\hline TV & 10 & Kalmykova, Patrício, Rosado, and Berg (2015)) \\
\hline CF & 15 & ATD Homeinspection (2010); Franco, Shaker, Kalubi, and Hostettler (2017) \\
\hline FR & 15 & ATD Homeinspection (2010); Cooper, Skelton, Moynihan, and Allwood (2014) \\
\hline RAC & 10 & ATD Homeinspection (2010); Wan et al. (2011) \\
\hline WM & 15 & ATD Homeinspection (2010); Bressanelli, Perona, and Saccani (2017) \\
\hline COM & 5 & ATD Homeinspection (2010) \\
\hline WEP & 15 & Haque, Islam, Islam, Haniu, and Akhter (2017) \\
\hline
\end{tabular}

${ }^{\mathrm{a}}$ In the residential sector a use of $4 \mathrm{~h} /$ day is assumed. 
TABLE 3 Operating time of the main appliances typically used in India's households

\begin{tabular}{|c|c|c|c|c|c|c|c|c|c|c|c|c|c|c|}
\hline \multirow[b]{2}{*}{ Appliance/End-use } & \multicolumn{2}{|c|}{ TERI (2006) } & \multicolumn{2}{|c|}{$\begin{array}{l}\text { McNeil, Iyer, Meyers, } \\
\text { Letschert, and } \\
\text { McMahon (2005) }\end{array}$} & \multicolumn{2}{|l|}{$\begin{array}{l}\text { CMIE } \\
(2000)\end{array}$} & \multicolumn{2}{|c|}{$\begin{array}{l}\text { Murthy } \\
\text { et al. (2001) }\end{array}$} & \multicolumn{2}{|c|}{$\begin{array}{l}\text { Boegle, Singh, and } \\
\text { Sant (2007) }\end{array}$} & \multicolumn{2}{|c|}{$\begin{array}{l}\text { World } \\
\text { Bank (2008) }\end{array}$} & \multicolumn{2}{|c|}{$\begin{array}{l}\text { Singh, Martins, and } \\
\text { Henriques (2016) }\end{array}$} \\
\hline & hr/day & days & hr/day & days & hr/day & days & hr/day & days & hr/day & days & hr/day & days & hr/day & days \\
\hline FR & 24 & 365 & 24 & 365 & 24 & 365 & 24 & 365 & & & 24 & 365 & 24 & 365 \\
\hline TV & 3 & 365 & & & 3 & 350 & $3.6-3.9$ & 365 & 6 & 365 & 4 & 365 & 6 & 365 \\
\hline EG & 1 & 150 & & 2 & 250 & 1 & 365 & 1 & 200 & 0.4 & 365 & 0.5 & 200 & \\
\hline WM & 1 & 200 & & 1 & 350 & 1 & 365 & 1 & 250 & 1 & 365 & 1 & 365 & \\
\hline $\mathrm{COM}$ & & 3 & 250 & 3 & 365 & 4 & 350 & & & & & & & \\
\hline WEP & & & & 1.5 & 365 & & & & & & & & & \\
\hline
\end{tabular}

related to institutional, human, financial, and political dimensions (Pereira \& Da Silva, 2017). In the next sections, a brief description will be provided regarding several dimensions of energy efficiency governance in India.

\section{1 | A brief overview of the energy efficiency governance structure in India}

Figure 2 depicts India's energy efficiency governance structure. In India, the BEE is the major institutional body aimed at developing, implementing, and monitoring energy efficiency policies. The National Institution for Transforming India (NITI), previously known as the Planning Commission, is also largely responsible for governing the energy policy landscape in the country. In 2010, the Government of India created the Energy Efficiency Services Limited (EESL), the world largest public energy saving company (ESCO) which also acts as the resource center for capacity building for electricity distribution companies as well as financial institutions such as the India Infrastructure Finance Company Ltd (IIFCL), the Export-Import Bank of India (EXIM Bank), the Small Industries Development Bank of India (SIDBI), and the National Housing Bank (NHB) which, in one way or the other, provide funding to energy efficiency projects.

\section{2 | Energy efficiency strategies and action plans}

In 2008, the National Action Plan on Climate Change (NAPCC) in India was launched and it identified a number of measures that simultaneously advanced the country's development and climate change-related objectives of adaptation and mitigation (Government of India, 2008; Kumar, 2013).

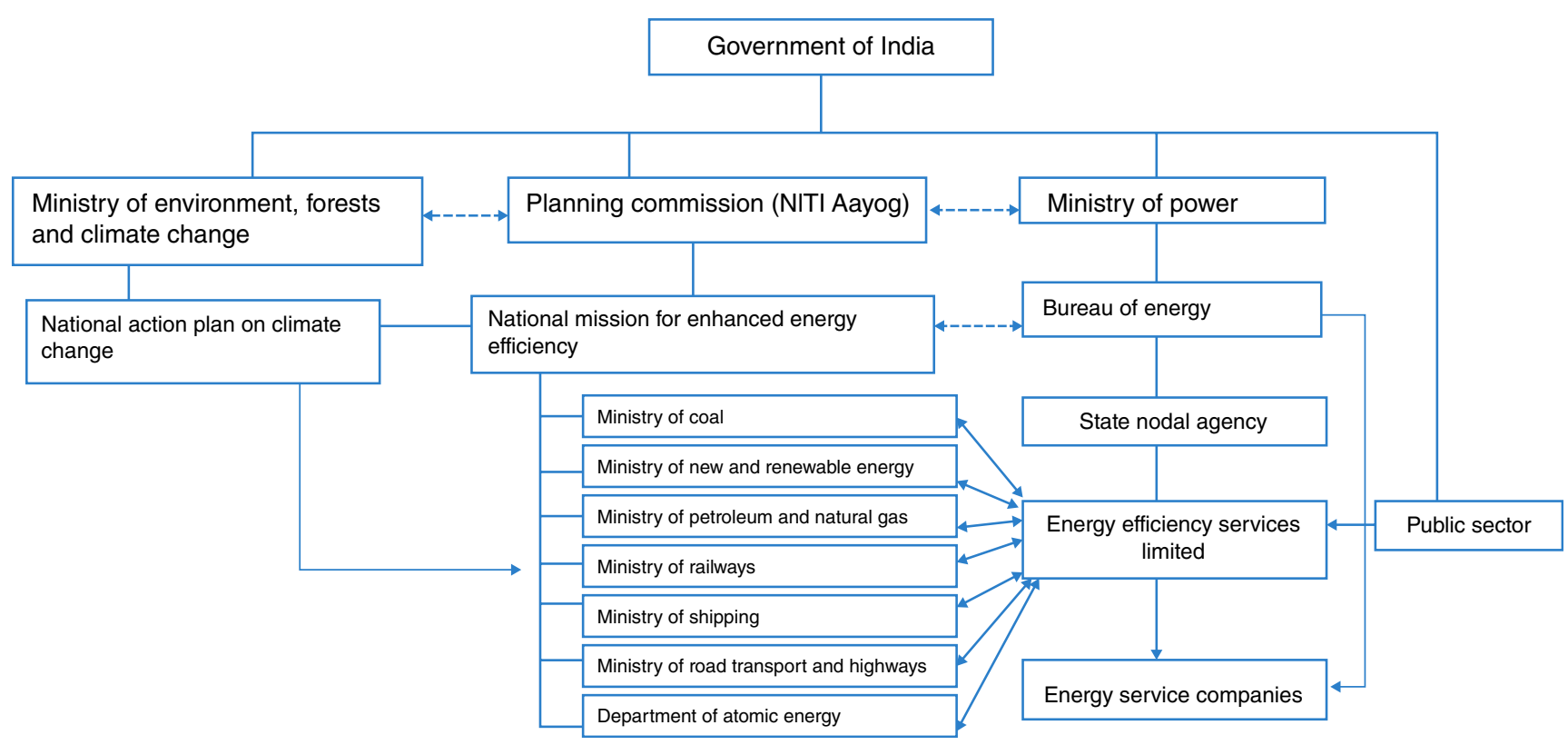

FIGURE 2 India's energy efficiency governance structure 
The National Mission for Enhanced Energy Efficiency (NMEEE) is one of the eight missions under the NAPCC. The NMEEE aims to strengthen the energy efficiency market by creating regulatory and policy regimes and envisages to foster innovative and sustainable business models for the energy efficiency sector (BEE, 2012). In this framework, four initiatives were adopted to enhance energy efficiency in energy intensive industries as follows:

1. The Perform Achieve and Trade Scheme (PAT), which is a market-based mechanism to enhance the cost effectiveness in improving the energy efficiency in energy intensive industries through certification of energy saving which can be traded.

2. Market Transformation for Energy Efficiency (MTEE), for accelerating the shift to energy-efficient appliances in designated sectors through innovative measures to make the products more affordable.

3. An Energy Efficiency Financing Platform (EEFP), for the creation of mechanisms that would help finance demand side management program in all sectors by capturing future energy savings.

4. A Framework for Energy-Efficient Economic Development (FEEED), for the development of fiscal instruments to promote energy efficiency.

United Nations Framework Convention on Climate Change (UNFCCC) is an international treaty adopted in 1992 committed to the reduction of GHG emissions toward the implementation of the Kyoto Protocol. About 192 countries participated in the UNFCCC framework and have defined national action plans. The first countries responsible for the formulation of national strategies aimed at reducing the energy consumption were the United States (1992), Australia (1998), and the United Kingdom (1999). Table 4 displays examples of some of the earliest national energy efficiency strategies and action plans adopted in various countries.

The effectiveness of the energy efficiency strategy and of the adopted action plans in India can be seen on several aspects:

- The government of India has put forward a set of intertwined legislative instruments to improve the EE of the country. One example is the 2001 Energy Conservation (EC) Act which includes instruments such as Designated Consumers, S\&L of Appliances, and the Energy Conservation Building Codes. It also created the BEE, in charge of implementing the EC Act, as well as the Energy Conservation Fund, as a complete set of instruments aiming at reducing the energy intensity of India's economy.

- There has been also a specialized action toward specific activity sectors, issuing standards and guidelines, of which the Energy Conservation Building Codes is an example, as well as the cases of Demand-Side Management (DSM) in agriculture, energy efficiency improvement in municipal water pumping and in domestic lighting.

- Following the EC Act, the 2003 Electricity Act aims at efficient use of energy and energy savings through EET and DSM in various activity sectors.

TABLE 4 Examples of some energy efficiency strategies and action plans

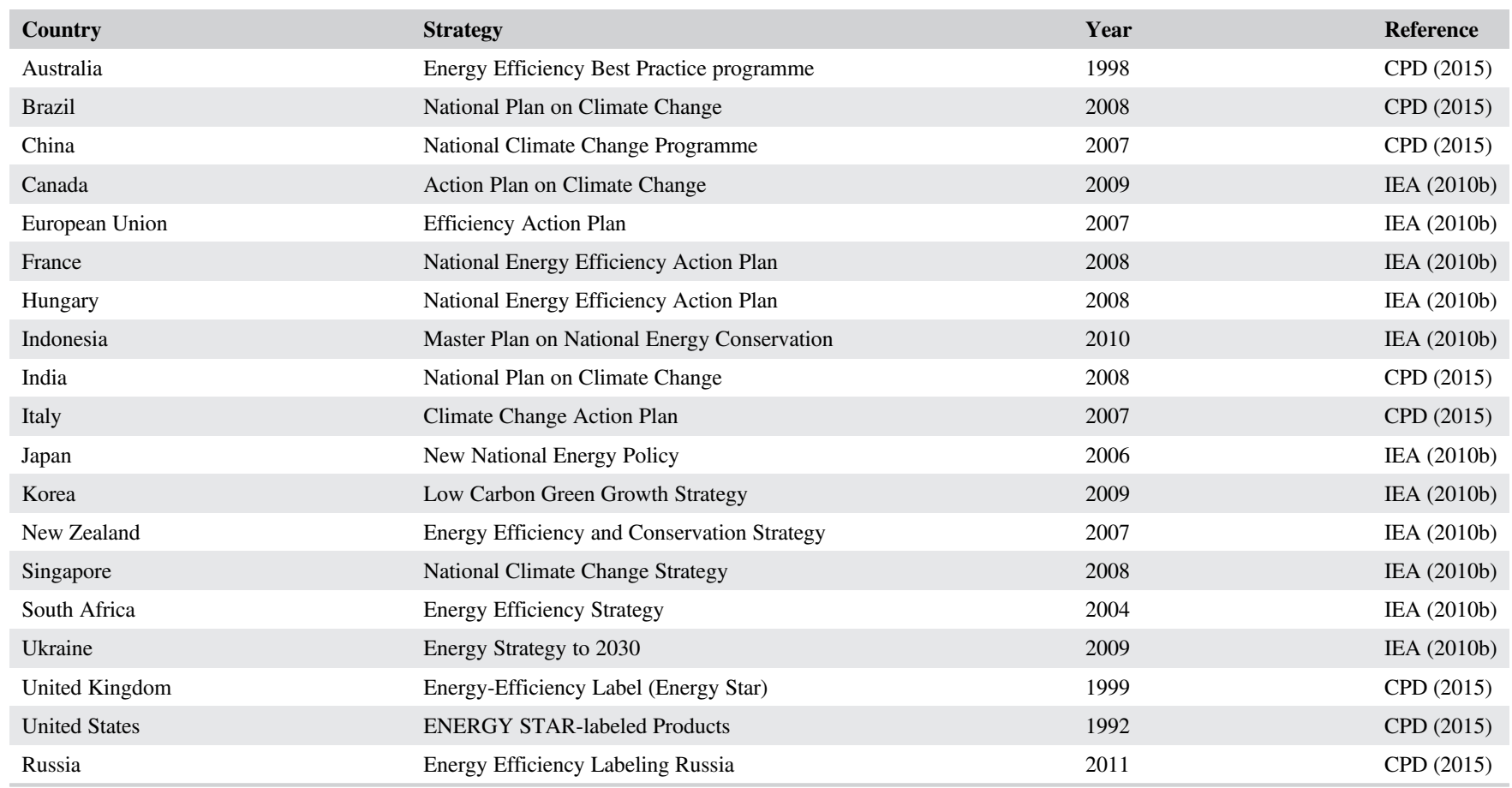


- An example of an awareness raising program is the national scheme designated Bachat Lamp Yojana (BLY), also known as "Save lamp schemes" for promoting energy-efficient and high-quality CFLs as a replacement for incandescent bulbs in households. The BLY scheme successfully registered under UNFCCC-Executive Board on April 29, 2010 under the Clean Development Mechanism (CDM) of the Kyoto Protocol to reduce GHGs from power plants connected to the grid.

- In 2006, India adopted an integrated energy policy which became a comprehensive National policy in 2012. This integrated policy approach will explore alternative technologies and possible synergies to increase energy systems efficiency while meeting appropriate requirement for energy services.

\subsection{Standard and labeling programs in India}

Over the last decades, there has been an increasing recognition of the importance of energy efficiency in India's energy policy agenda which resulted in an Energy Conservation Act in 2001 and in an Electricity Act in 2003. One of the energy efficiency initiatives specifically targeting energy-efficient appliances in India was launched by the Minister of Power on May 18, 2006 consisting of the adoption of an S\&L scheme. Later on, the BEE incorporated the USEPA's energy star rating system into India's S\&L scheme, considering both mandatory and voluntary labeling. The scheme contemplated 21 types of technologies (BEE, 2006, 2009) and raised awareness regarding the energy performance of the appliances available on the market, with the least and most energy-efficient appliances being rated with 1-5 stars, respectively (Parikh \& Parikh, 2016).

The star labeling scheme combines comparative star labels according to minimum energy performance standards (MEPS) (Abhyankar, Shah, Letschert, \& Phadke, 2017). There are two types of labels which are depicted in Figure 3: (a) small labels which are assigned to small household appliances - that is, tube lights, computers, laptops, CF, and TV; and (b) big labels for the other type of appliances - that is, WM, refrigerators, RACs, and electric geysers. The timeline for the implementation of the S\&L program in India is illustrated in Figure 4. In Table 5, it is possible to see the appliances subject to mandatory/voluntary labeling schemes and without any labeling schemes. State and central electricity regulatory commissions (ERC) are also involved in energy efficiency improvement initiatives. In this framework, ERC are only targeting lighting, RAC and CF in Maharashtra and Delhi (Singh, Sant, \& Chunekar, 2012). Table 6 presents the type of labeling schemes that are being adopted in other countries.

The S\&L program was introduced by the central Government to moderate energy demand growth in the residential sectors. The implementation of an S\&L scheme is under the responsibility of the BEE, the Ministry of Power, the BIS, consumers associations, manufacturers associations, and the National Accreditation Board for Testing and Calibration Laboratories (NABL) (Jairaj, Agarwal, Parthasarathy, \& Martin, 2016). The standard setting process is led by committees established by the BEE (Figure 5). Energy labeling usually starts with a voluntary stage requiring a minimum energy performance but in due

BEE - Big label

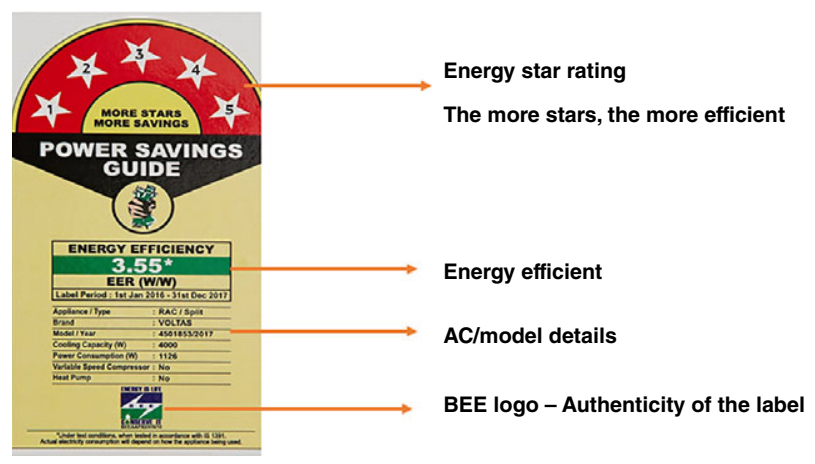

BEE Small label

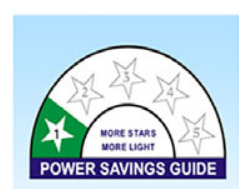

FIGURE 3 BEE label for appliances

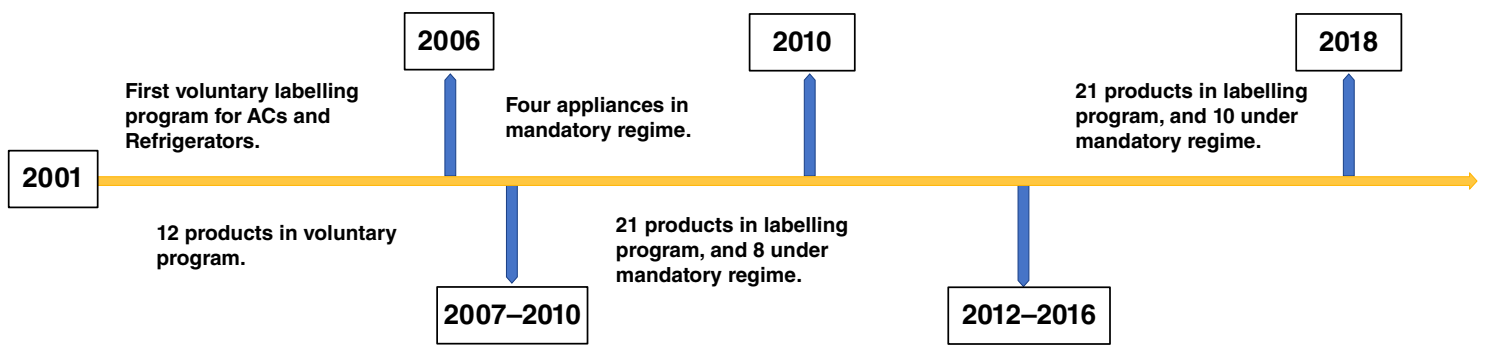

FIGURE 4 Timeline for the S\&L program in India 
TABLE 5 Appliances/End-use technologies with and without labeling schemes in the residential sector (India)

\begin{tabular}{ll} 
With energy label scheme & Without energy label scheme \\
\hline Tubular fluorescent lamps (TFL) & Tape recorder, CD player \\
\hline Refrigerator (FR) & Radio \\
\hline Television (TV) & Air cooler \\
\hline Room air conditioner (RAC) & Room heater \\
\hline Ceiling fan (CF) & Set-top box \\
\hline Electric water heating (EG) & DVD players \\
\hline Washing machine (WM) & Electric oven \\
\hline Computer (COM) & Incandescent bulb \\
\hline Cooking stove LPG & Compact fluorescent lamp (CFL) \\
\hline Water electric pump (WEP) & Toaster \\
\hline
\end{tabular}

time it is expected that these will become mandatory (BEE, 2006). Although there is lack of additional information or explanation regarding the transition of energy labels from voluntary to mandatory, the process of labeling transition is generally reviewed every 2 years. Table 7 displays the chronogram with the major energy efficiency initiatives and policies specifically addressing the appliances typically used in India's households.

\section{6 | MARKET TRANSFORMATION AND ENERGY EFFICIENCY}

Energy efficiency improvement is a rather complex phenomenon, which is affected by the decisions of different actors: manufacturers, retailers, consumers, professional consultants, and so on. Although energy efficiency is economically sustainable in that investments are repaid in a few years, the measures actually taken to improve energy efficiency in general, and electricity end-use in particular, are far less than strict economic judgment would justify: this is partly because the relevant decision making is dispersed between different actors (Bertoldi, 1999). In the context of energy efficiency, MT is a process whereby energy-efficiency innovation are stimulated and over time penetrate a large portion of the eligible market.

According to American Council for an Energy-Efficient Economy (ACEEE), "the term market transformation refers to the strategic process of intervening in a market to create lasting change in market behavior by removing identified barriers or exploiting opportunities to accelerate the adoption of all cost-effective energy efficiency as a matter of standard practice" (Vaidya, Vasudevan, \& Cherail, 1996).

The technological diffusion of energy efficiency generally follows an S curve (De La Rue Du Can, Leventis, Phadke, \& Gopal, 2014; Rogers, 1963). With the foregoing in mind, a double $\mathrm{S}$ curve is proposed in Figure 6 that illustrates the influence of the process of MT on the rate of penetration of energy-efficient appliances.

At the first early adoption stages, while innovation takes place and the maturity of the technology is not reached, the market penetration is less intense. Subsequently, the mass adoption stage of energy-efficient appliances is achieved due to incentive designed programs. Finally, after establishing the effective implementation of the last stage, the adoption rates start increasing in a steadier manner. Overcoming the gap between the business as usual and the best available technology options requires a process of MT.

MT depends on incentive designed programs which increase demand, and thus market penetration, of early stage highly efficient technologies. The mass increase of demand of such technologies leads to economies of scale for the manufacturers and positive learning effects, streamlining production processes and decreasing the costs of production (De La Rue Du Can et al., 2014).

Because of its inherent characteristics, in the case of India, attaining an effective MT mechanism is particularly important. Specifically, technology development can create a market demand and market demand also can accelerate the development of technology innovation processes. The first relationship is usually designated technology push and the second is usually designated demand-pull (Choi, 2017; Nemet, 2009; Peters, Schneider, Griesshaber, \& Hoffmann, 2012). Technology-push favoring policies help decreasing the production cost (private cost) of innovative products-for instance, by mean of targeted R\&D funding support. Demand-pull policies increase the private payoff of successful innovation through several possible mechanisms: intellectual property protection, tax credits and rebates for consumers of new technologies, government procurement, technology mandates, regulatory standards, and taxes on competing technologies (Girod et al., 2017). The Unant Jyoti by affordable LEDs for all (UJALA) program is one example of both demand-pull and technology-push policy. Under this program, 295 million LED lights were sold, bringing the price per light down from around USD \$5 to less than \$1 per light bulb in 2016 (CLASP, 2017). 


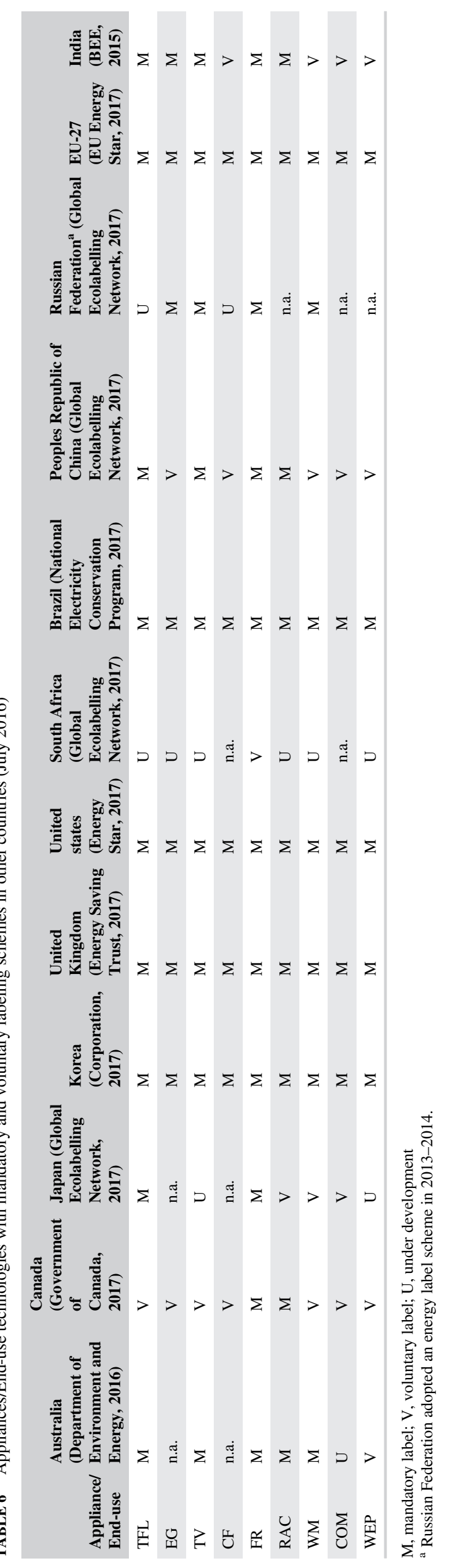




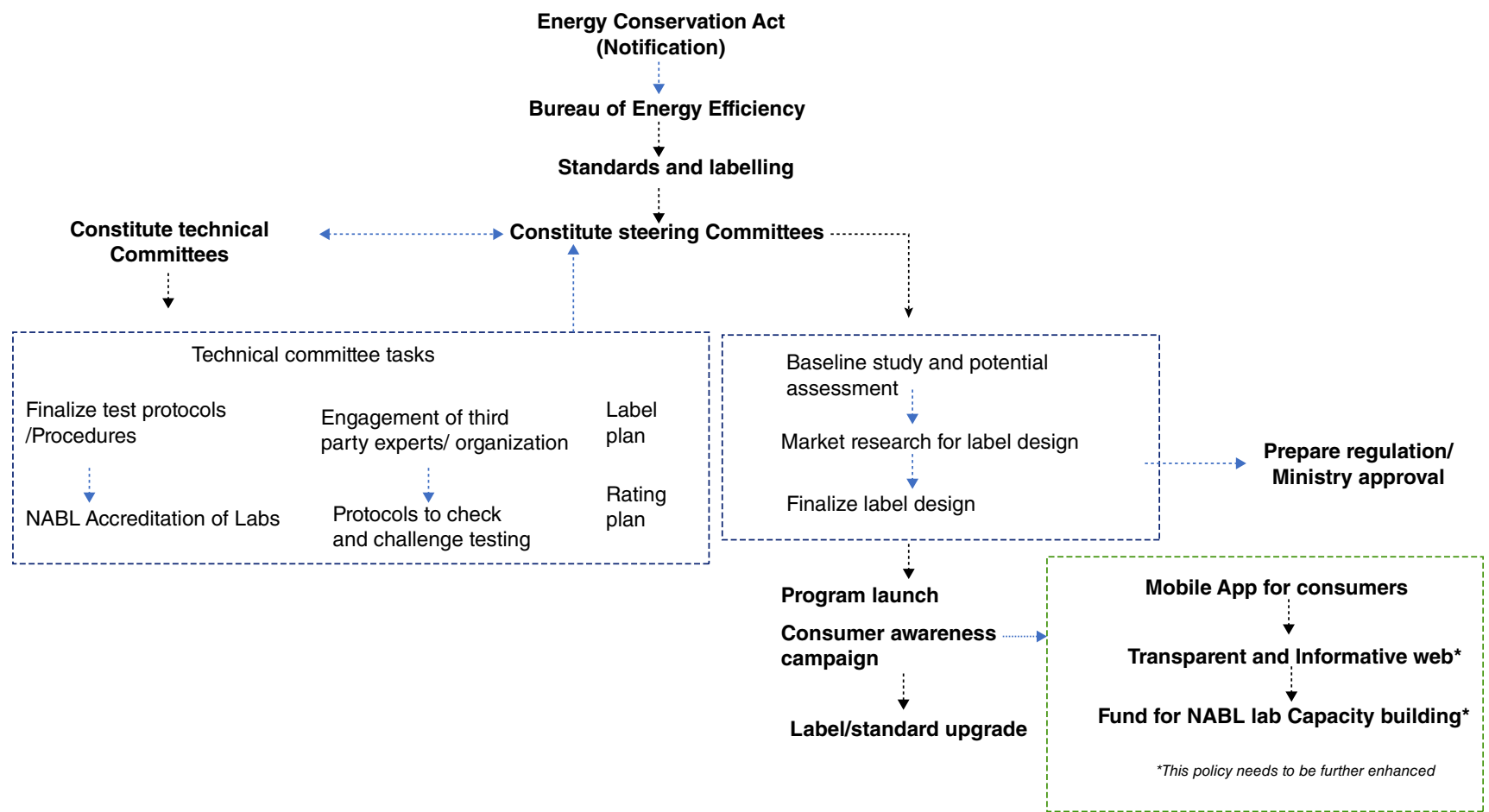

FIGURE 5 S\&L program process (adapted from Jairaj et al., 2016 and Sundarmoorthy \& Walia, 2017)

\section{7 | CO-BENEFITS OBTAINED WITH THE USE OF ENERGY-EFFICIENT APPLIANCES}

Energy efficiency can bring multiple benefits, such as enhancing the sustainability of the energy system, supporting strategic objectives for economic and social development, promoting environmental goals, and increasing prosperity (International Energy Agency, 2014; Ryan \& Campbell, 2012). Besides being a cost-effective driver for attaining reduced energy consumption, the adoption of energy conservation measures (ECM) also allows achieving additional "cobenefits" (Thomas et al.,

TABLE 7 Energy efficiency initiatives and policies specifically addressing the appliances typically used in India's households

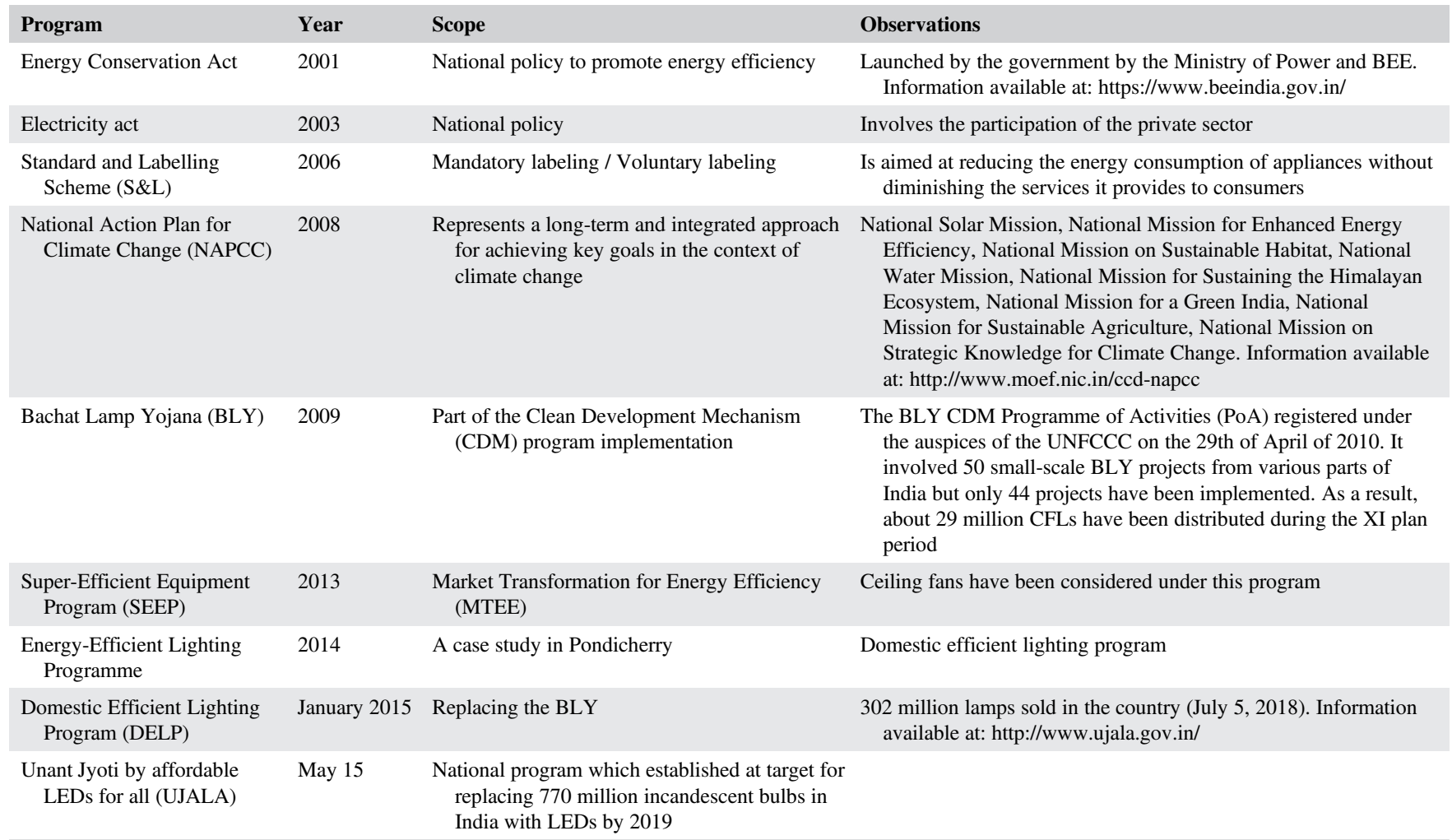




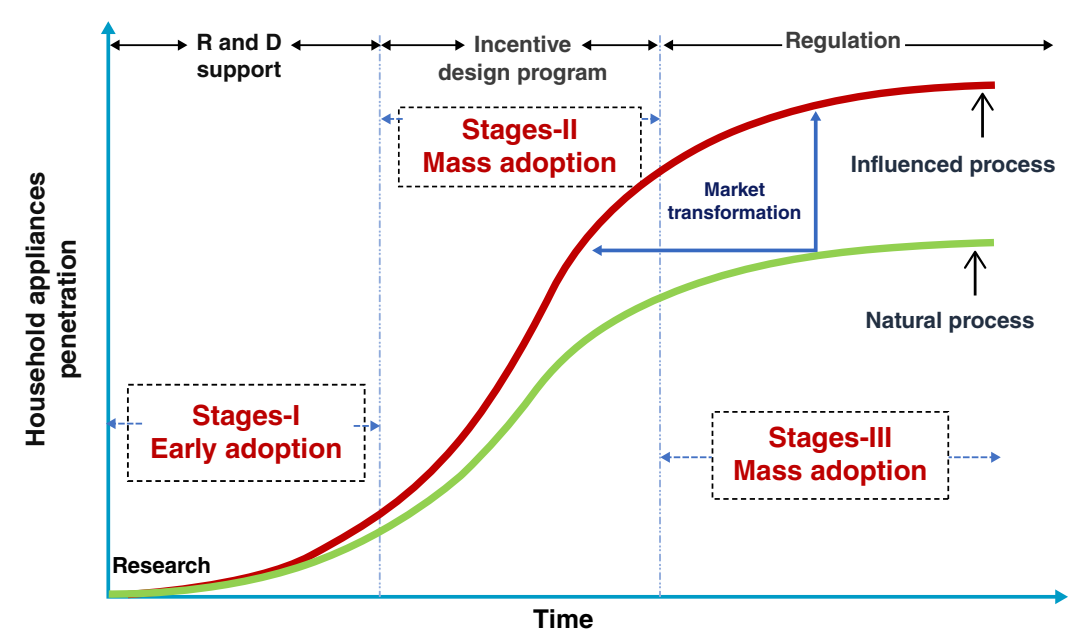

FIGURE 6 Double S curve illustrating the market transformation effect

2015). The reduction of the energy bill for households might be regarded as the main investor's direct motivation for purchasing energy-efficient appliances, but there are also other cobenefits. Figure 7 illustrates the major cobenefits obtained as a result of investing in energy-efficient appliances. In what concerns society, poverty alleviation might be expected due to the increase of disposal income with the reduction of the energy bill. However, with the rise of disposable income, private household's consumption also increases leading to a positive impact on gross domestic product and thus on national economy. The reduction of energy demand increases energy security and reduces GHG emissions during manufacturing and energy production phases contributing to positive environmental outcomes. The expected improvement of air quality and of indoor comfort levels with energy-efficient appliances reduces respiratory diseases, among other, having a positive impact on health.

\section{I BARRIERS TO THE ADOPTION OF ENERGY-EFFICIENT APPLIANCES}

\section{1 | Global barriers}

The term energy efficiency barrier refers to a mechanism that inhibits a decision or behavior that appears to be efficient both economically and from an energy point of view (Makridou, 2016). Barriers can either complicate the adoption of cost-

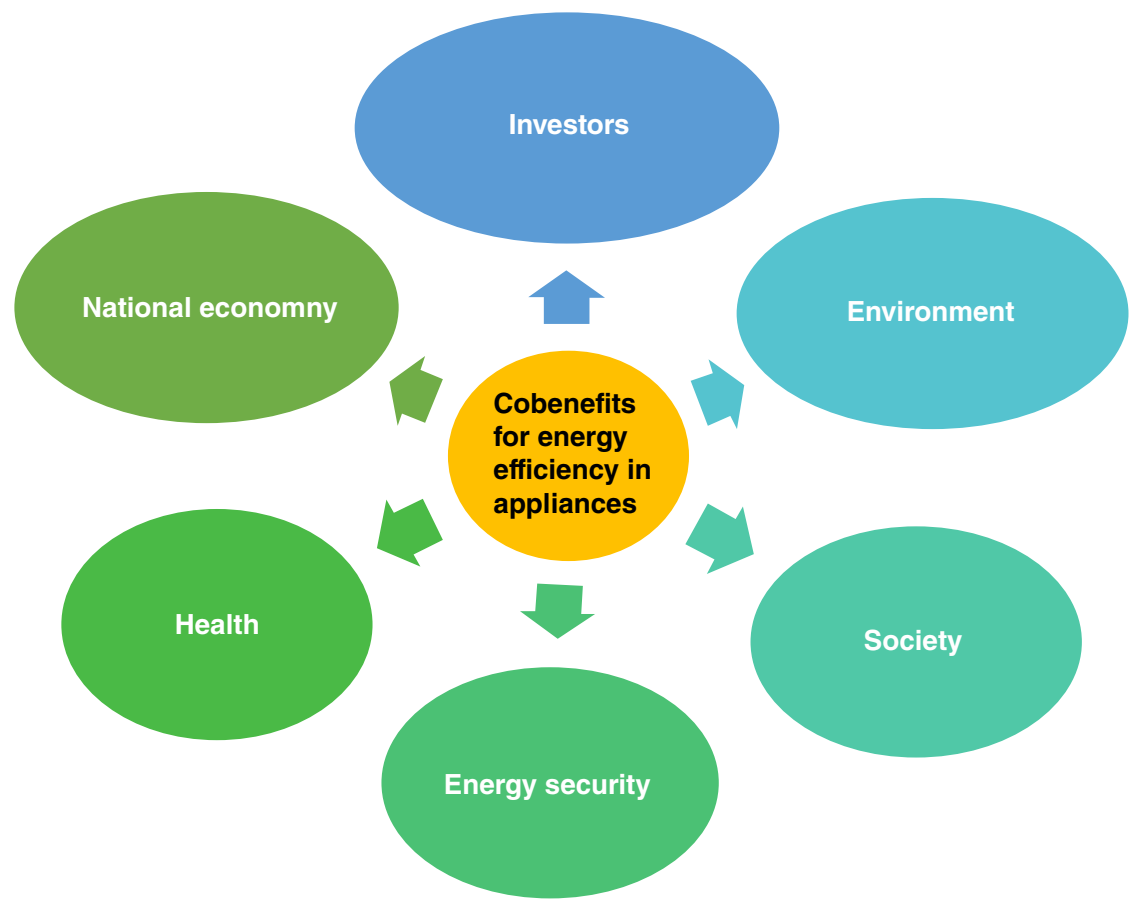


TABLE 8 Examples of barriers (adapted from International Energy Agency, 2010)

\begin{tabular}{|ll}
\hline Barrier & Examples \\
\hline Market & - Market organization and price distortions prevent customers from appraising the true value of energy efficiency \\
\hline Financial & - Split incentive problems created when investors cannot capture the benefits of improved efficiency \\
& - Perception of energy efficiency investments as complicated and risky \\
& - Lack of awareness of financial benefits on the part of financial institutions \\
\hline Information and awareness & - Lack of information and understanding to make rational consumption and investment decisions on the part of consumers \\
\hline Regulatory and institutional & - Energy tariffs that discourage energy efficiency investment \\
& - Incentive structures encourage energy providers to sell energy rather than invest in cost-effective energy efficiency \\
\hline Technical & - Institutional bias toward supply-side investments \\
\hline
\end{tabular}

effective energy efficiency technologies or slow down their diffusion. Some examples of these barriers are high investment cost, lack of financing mechanisms in the field, lack of awareness, cost of production and risk of disruption-Table 8. There are many proposals to categorize these barriers, which can be divided in two groups (Makridou, 2016): structural (distortion in fuel prices, uncertainty about the future, or government policies) and behavioral barriers (like the perceived risk of energy efficiency investments, lack of information or lack of life-cycle thinking on the costs and savings). Other possible classifications were proposed by Eric Hirst (1990), Lohani \& Azimi (1992), Reddy (1991), and Steve Nadel (1994)).

The possible categorization herein followed was proposed by Steve Nadel (1994) and identifies six market barriers (Golove \& Eto, 1996).

\subsection{1 | Misplaced incentives}

Misplaced incentives are those incentives that do not actually benefit the person who is trying to adopt improved EEM, the majority being related to the residential sector (Rohdin \& Thollander, 2006; Schleich, 2004; Schleich \& Gruber, 2008). For example, if a renter decides about the energy use and pays the bills while the owner decides about the installed equipment (and chooses the cheapest alternative) the most cost-efficient combination will probably not be chosen.

\subsection{2 | Lack of access to financing}

This type of barrier is related with up-front costs and the corresponding lack of liquidity, namely for low-income individuals or small business owners (Hrovatin, Dol Sak, \& Zori, 2016; Nagesha \& Balachandra, 2006; Sorrell, 2004; Sorrell, 2015; Trianni, Cagno, Thollander, \& Backlund, 2013). Moreover, there is a lack of awareness of the financial benefits associated to this type of investments on the part of financial institutions, preventing the access to capital for small investors. Finally, the perception of energy-efficient investments as complicated and risky might also subsist.

\subsection{3 | Flaws in the market structure}

A typical market failure is related to the fact that the existence of powerful firms might impair the arrival of other competitors supplying other EET, eventually more cost-effective (Chai \& Yeo, 2012; Hrovatin et al., 2016; Schleich, 2009; Schleich \& Gruber, 2008; Trianni et al., 2013).

\subsection{4 | Mispricing imposed by regulation}

This market barrier refers to the fact that energy regulated prices might discourage the adoption of EEM (Rohdin \& Thollander, 2006; Schleich, 2004).

\subsection{5 | Lack of information or misinformation}

Sometimes the consumers are not well informed and do not understand how to make rational consumption and investment decisions (Schleich, 2004).

\subsection{6 | Lack of standard practice}

The Global Environment Facility (GEF) and the CLASP were the main drivers of MT of energy efficiency technologies in developing countries. In fact, several financed energy efficiency programs took place in India by means of the GEF through the United Nations Development Programme (UNDP) and the CLASP. However, developing countries have particular barriers for MT and energy efficiency (Birner \& Martinot, 2005), namely: few experiences on fostering energy efficiency, through the use of market-based schemes and informational issues as awareness raising; absence of standard practices regarding programs for the adoption of EEM; lack of data; lack of regulation and organization with local governments and the 


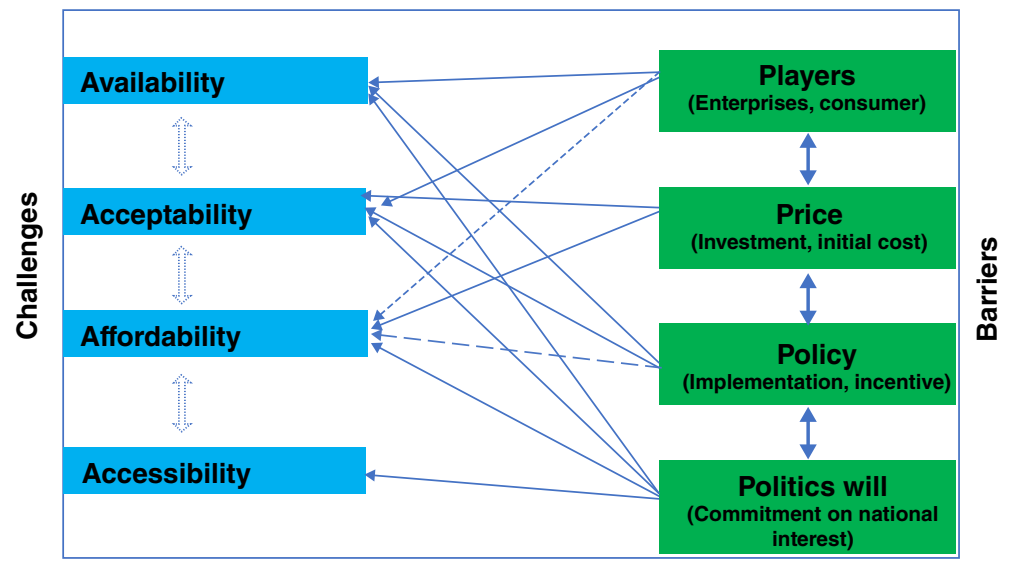

FIGURE 8 Energy-efficient technology challenges and barriers

private sector to foster energy efficiency; incipient energy efficiency markets for high EET; lack of government-based policy instruments; lack of governance capacity aiming for energy efficiency markets.

\section{2 | India's national barriers}

The adoption of energy-efficient appliances has faced different barriers in India's residential sector. The main barriers are the high initial cost of efficient technology and the lack of awareness or lack of interest of consumers. Heterogeneity of consumers also plays a role, since middle class families live mainly in urban areas while low income families live mainly in rural areas. The 4P's major barriers identified in this paper are: Players, Price, Policy, and Political will. They need to be addressed to create an effect of energy efficiency governance by policymakers (see Figure 8). The first of the four Ps stands for player. A player is any business oriented enterprise committed to ensure the supply of some energy-efficient product to the market to fulfill some consumers' need. The second P refers to the price barrier. Traditional, not efficient products are usually available on the market at much lower prices than efficient ones, since established manufacturers resist to make the investments needed to adapt their production lines. The third P stands for policy. India is still lacking an effective national policy plan to promote energy-efficient appliances in the residential sector. Multiple ministries related to energy issues cause a high complexity of the state government involvement, often obstructing institutional coordination for coherent central policy making.

India is a democratic country where political leaders are capable of influencing the decision making process. Political will is also important to government investment and implementation processes, which cannot occur without a strong commitment of political leaders.

\section{I CONCLUSIONS}

In this study, a review is presented of energy-efficient end-use appliance technologies and energy efficiency policy initiatives across national level for India's residential sector, based on literature research. Some of the main conclusions are drawn:

- India's residential sector shows higher energy consumption than in other developing countries, almost reaching the share of some developed countries like Germany and Italy (23-26\% approx.)

- India's S\&L scheme has been implemented during the last decades, considering both mandatory and voluntary labeling schemes, contemplating 21 types of technologies, of which only nine (only five mandatory) electrical end-use appliances in the residential sector.

- S\&L, BLY, Super-Efficient Equipment Program (SEEP), Domestic Efficient Lighting Program (DELP), and UJALA energy efficiency initiatives and policies specifically address the appliances typically used in India's households. However, we found that utility program BLY and the second program DELP is expanding the Unant Jyoti program by affordable LEDs for all (UJALA). Both utility programs are based on lighting technologies. India is still lacking other large-scale policies beyond the S\&L scheme.

- Energy-efficient appliances can bring multiple cobenefits, such as enhancing investment, alleviating energy poverty due to the increase of disposal income from the reduction of energy bills, causing a positive impact on the national economy. Reduction in energy demand also improves environmental impacts by reducing GHG emissions, with a positive impact on health. 
- A double S curve representation is used to illustrate the effect of MT programs on the acceleration of the diffusion of efficient appliances on the market.

- Barrier types are identified that prevent the adoption of energy-efficient appliances, namely, financial, technical, related to information and awareness, or to regulatory and institutional incentives, or to market structure.

- International Agencies like UNDP, GEF, and CLASP should focus on some pilot case studies in real households.

- Since energy efficiency and energy security have a prominent role on the economic and social development of all countries, it is crucial to incorporate energy efficiency concerns in any economic program (UNFCCC, 2010).

- Therefore, developing countries like India need to promote EEM. In this context, energy self-sufficiency plays a critical role in the economic/social development and prosperity of these countries. Energy initiatives are directly associated with general political options related to tariff incentives, social cohesion, national alliances, and bilateral commercial agreements. At the same time, energy efficiency planning should include several aspects, such as energy saving targets, instruments to promote innovative technologies development and diffusion.

\section{ACKNOWLEDGMENTS}

The authors acknowledge Energy for Sustainability Initiative, University of Coimbra, Portugal, and the financial support from FCT/Portugal for PhD scholarship SFRH/BD/52308/2013 and MIT-Portugal Program. This work has also been supported by the Portuguese Foundation for Science and Technology (FCT) under project grant UID/MULTI/00308/2013.

\section{CONFLICT OF INTEREST}

The authors have declared no conflicts of interest for this article.

\section{RELATED WIRES ARTICLES}

Global experience with energy efficiency and the role of the private sector

Improving energy efficiency in India: need for a targeted and tailored strategy

\section{ORCID}

Vivek Kumar Singh (D) http://orcid.org/0000-0003-1547-0323

\section{FURTHER READING}

EU Energy Star (2017). Database of products that are available on the EU markets and qualified under the latest active ENERGY STAR specifications. Retrieved from https://www.eu-energystar.org

Foxon, T., Köhler, J., \& Oughton, C. (2008). Innovation for a low carbon economy: Economic, institutional and management approaches. England: Edward Elgar Publishing.

Gupta, J., \& Ivanova, A. (2009). Global energy efficiency governance in the context of climate politics. Energy Efficiency, 2(4), 339-352. https://doi.org/10.1007/ s12053-008-9036-4

Singh, V. K., Henriques, C. O., \& Martins, A. G. (2018). Fostering investment on energy efficient appliances in India - A multi-perspective economic input-output lifecycle assessment. Energy, 149, 1022-1035. https://doi.org/10.1016/j.energy.2018.01.140

Vivoda, V. (2010). Evaluating energy security in the Asia-Pacific region: A novel methodological approach. Energy Policy, 38(9), 5258-5263. https://doi.org/10.1016/j. enpol.2010.05.028

\section{REFERENCES}

AAB. (2014). Technical note - IEC 60034-30-1 standard on efficiency classes for low voltage AC motors. Retrieved from https:/library.e.abb.com/ public/1018a82e36b29462c1257d41002b3470/TM025EN08-2014IEC60034-30-1_lowres.pdf.

Abhyankar, N., Shah, N., Letschert, V., \& Phadke, A. (2017). Assessing the cost-effective energy saving potential from top-10 appliances in India. Paper presented at the 9th International Conference on Energy Efficiency in Domestic Appliances and Lighting (EEDAL), Irvine, CA. Retrieved from https://ies.lbl.gov/sites/default/ files/india_appliance_ee_potential_eedal_conference_paper_0.pdf

AEEE. (2015). Evaluating market response to the appliance standards and labelling programme-A status report. Retrieved from http://www.aeee.in/wp-content/ uploads/2016/11/SL-Mkt-Evaluation-Final-Report.pdf

Aggarwal, D., \& Singh Rana, D. (2016). Appliances guide energy efficient washing machines country India. Retrieved from http://www.bigee.net/media/filer_ public/2016/09/01/energy_efficient_washing_machines_in_india.pdf

ATD Homeinspection. (2010). Average life span of homes, appliances, and mechanicals. Retrieved from https://www.atdhomeinspection.com/advice/averageproduct-life/

Balasubramanian, S. (2017). Superfans could reduce India's carbon footprint—India climate dialogue. Retrieved from http:/indiaclimatedialogue.net/2017/11/09/ superfans-reduce-indias-carbon-footprint/

BEE. (2006). Standards \& Labelling programme (S \& L). Retrieved from https://beeindia.gov.in/content/s-1

BEE. (2007). Energy conservation building code 2007. Retrieved from https://townplanning.gujarat.gov.in/Documents/ECBC-final-May-2007.pdf 
BEE. (2009). Progress on standards and labelling in India. Presentation by G. Pandian on the International Conference on Standby Power, India 2008. Organized by Indian Indian Bureau of Energy Efficiency/International Energy Agency (IEA). Retrieved from https://www.slideshare.net/ceciliabengtson/progress-of-standardsand-labelling-program-in-india-presented-by-mr-g-pandian-energy-economist-bureau-of-energy-efficiency-bee-india

BEE. (2012). National mission for enhanced energy efficiency. Retrieved from https://beeindia.gov.in/content/nmeee-0

BEE. (2015). Star labelled appliances. Retrieved from https://www.beeindia.gov.in/content/star-labelled-appliances

Bertoldi, P. (1999). European union efforts to promote more efficient appliances. In Energy efficiency in household appliances (pp. 79-88). Berlin, Heidelberg: Springer. https://doi.org/10.1007/978-3-642-60020-3_11

Bhattacharyya, S. C. (2014). Structural and macro-economic changes in India and the implications for the residential energy demand. WIREs Energy and Environment, 3(6), 535-539. https://doi.org/10.1002/wene.108

Bijli Bachao. (2016). Laptop and desktop energy comparison : Bijli Bachao. Retrieved from https://www.bijlibachao.com/appliances/laptop-and-desktop-energycomparison.html

BijliBachao. (2017). Replacing old or buying new, why a BEE 5 star rated refrigerator always makes sense: Bijli Bachao. Retrieved from https://www.bijlibachao.com/ refrigerators/replacing-old-or-buying-new-why-a-bee-5-star-rated-refrigerator-always-makes-sense.html

Birner, S., \& Martinot, E. (2005). Promoting energy-efficient products: GEF experience and lessons for market transformation in developing countries. Energy Policy, 33(14), 1765-1779. https://doi.org/10.1016/j.enpol.2004.01.015

Boegle, A., Singh, D, \& Sant G. (2007). Energy saving potential in Indian households from improved appliance efficiency Prayas energy group Pune. Retrieved http:// www.prayaspune.org/peg/media/k2/attachments/energy_saving_potential_from_indian_households_from_appliance_efficiency_108A01.pdf

Bressanelli, G., Perona, M., \& Saccani, N. (2017). Reshaping the washing machine industry through circular economy and product-service system business models. Procedia CIRP, 64, 43-48. https://doi.org/10.1016/j.procir.2017.03.065

Bukarica, V., \& Tomšić, Ž. (2017). Energy efficiency policy evaluation by moving from techno-economic towards whole society perspective on energy efficiency market. Renewable and Sustainable Energy Reviews, 70, 968-975. https://doi.org/10.1016/j.rser.2016.12.002

CEA. (2017). Growth of electricity sector in India from 1947-2017. Retrieved from http://www.cea.nic.in/reports/others/planning/pdm/growth_2017.pdf

Chai, K.-H., \& Yeo, C. (2012). Overcoming energy efficiency barriers through systems approach-A conceptual framework. Energy Policy, 46, 460-472. https://doi. org/10.1016/J.ENPOL.2012.04.012

Choi, H. (2017). Technology-push and demand-pull factors in emerging sectors: Evidence from the electric vehicle market. Industry and Innovation, 25, 1-20. https:// doi.org/10.1080/13662716.2017.1346502

Chunekar, A., \& Singh, D. (2013). India's Super-Efficient Equipment Program (SEEP). Retrieved from https://cleanenergysolutions.org/sites/default/files/ documents/2013-12-03-india-super-efficient-equipment-program.pdf

CLASP. (2015). Policy opportunities for more efficient residential water heating. Retrieved from https:/www.solarthermalworld.org/sites/gstec/files/news/ file/2016-04-18/clasp_study.pdf

CLASP. (2017). India: Leading on energy efficiency. Retrieved from https://clasp.ngo/updates/2017/india-leading-on-energy-efficiency

Cleaning Institute. (2010). High efficiency washers and detergents working in harmony to save energy and water. Retrieved from http://www.cleaninginstitute.org/ assets/1/page/he.pdf

CMIE. (2000). Energy supply-demand handbook 1993-1994 \& 1995-1996. India: International Energy Initiative.

Cooper, D. R., Skelton, A. C. H., Moynihan, M. C., \& Allwood, J. M. (2014). Component level strategies for exploiting the lifespan of steel in products. Resources, Conservation and Recycling, 84, 24-34. https://doi.org/10.1016/j.resconrec.2013.11.014

Corporation, K. E. M. (2017). Korea energy standards and labelling market transformation. Retrieved from www.kemco.or.kr

CPD. (2015). Browse countries in the database-Policy database. Retrieved from http://climatepolicydatabase.org/index.php?title=Browse_countries

Cravioto, J., Yasunaga, R., \& Yamasue, E. (2017). Comparative analysis of average time of use of home appliances. Procedia CIRP, 61, 657-662. https://doi.org/10. 1016/J.PROCIR.2016.11.248

De La Rue Du Can, S., Leventis, G., Phadke, A., \& Gopal, A. (2014). Design of incentive programs for accelerating penetration of energy-efficient appliances. Energy Policy, 72, 56-66. https://doi.org/10.1016/J.ENPOL.2014.04.035

Department of Energy. (2017). Tankless or demand-type water heaters. Retrieved from https://www.energy.gov/energysaver/water-heating/tankless-or-demandtype-water-heaters

Department of Environment and Energy. (2016). Guide: The energy rating label. Energy Rating. Retrieved from http://www.energyrating.gov.au/document/ guide-energy-rating-label

Drysdale, B., Wu, J., \& Jenkins, N. (2015). Flexible demand in the GB domestic electricity sector in 2030. Applied Energy, 139, 281-290. https://doi.org/10.1016/j. apenergy.2014.11.013

ELCOMA. (2014). Lighting industry in India. Electric lamp and component manufacturers association of India. Retrieved from http://www.elcomaindia.com/ wp-content/uploads/FINAL_2014_Lighting_Industry_India.pdf

ELCOMA. (2017). Lighting industry in India. Retrieved from http://www.elcomaindia.com/wp-content/uploads/Lighting-Industry-India-2017.pdf

Energy Saving Trust. (2017). Home energy efficiency. Retrieved from http://www.energysavingtrust.org.uk/home-energy-efficiency

Energy Star. (2009). ENERGY STAR ${ }^{\circledR}$ program requirements for computers-Partner commitments. Retrieved from https://www.energystar.gov/ia/partners/product_ specs/program_reqs/Computers_Program_Requirements.pdf

Energy Star. (2017). Product label certified product. Retrieved from https://www.energystar.gov/products/how-product-earns-energy-star-label

Engineerlive. (2013). Energy-efficient motors: New standard supports market. Retrieved from http://www.engineerlive.com/content/21855

Eric Hirst, M. B. (1990). Closing the efficiency gap: Barriers to the efficient use of energy. Resources, Conservation and Recycling, 3(4), 267-281. https://doi.org/10. 1016/0921-3449(90)90023-W

Franco, A., Shaker, M., Kalubi, D., \& Hostettler, S. (2017). A review of sustainable energy access and technologies for healthcare facilities in the Global South. Sustainable Energy Technologies and Assessments, 22, 92-105. https://doi.org/10.1016/J.SETA.2017.02.022

Ghosh, S. (2002). Electricity consumption and economic growth in India. Energy Policy, 30(2), 125-129. https://doi.org/10.1016/S0301-4215(01)00078-7

Girod, B., Stucki, T., \& Woerter, M. (2017). How do policies for efficient energy use in the household sector induce energy-efficiency innovation? An evaluation of European countries. Energy Policy, 103, 223-237. https://doi.org/10.1016/j.enpol.2016.12.054

Global Ecolabelling Network. (2017). Green certification standards by country. Retrieved from https://globalecolabelling.net/eco/green-certification-by-country/

Goetzler, W., Sutherland, T., \& Foley, K. (2014). Research \& Development roadmap for next-generation appliances. Retrieved from https://energy.gov/sites/prod/ files/2014/12/f19/Research and Development Roadmap for Next-Generation Appliances.pdf.

Golove, W. H., \& Eto, J. H. (1996). Market barriers to energy efficiency: A critical reappraisal of the rationale for public policies to promote energy efficiency. Retrieved from http://citeseerx.ist.psu.edu/viewdoc/download?doi=10.1.1.165.3714\&rep=rep1\&type=pdf

Government of Canada. (2017). The EnerGuide label. Natural Resources Canada. Retrieved from http://www.nrcan.gc.ca/energy/products/energuide/label/13609

Government of India. (2008). Integrated energy policy: Report of the expert committee. Retrieved from http://www.planningcommission.gov.in/reports/genrep/rep_ intengy.pdf 
Halonen, L., Tetri, E., \& Bhusal, P. (2010). Energy efficient electric lighting for buildings ECBCS annex 45. Retrieved from http://www.iea-ebc.org/fileadmin/user_ upload/docs/EBC_Annex_45_PSR.pdf

Haque, M. E., Islam, M. R., Islam, M. S., Haniu, H., \& Akhter, M. S. (2017). Life cycle cost and energy consumption behavior of submersible pumps using in the Barind area of Bangladesh. Energy Procedia, 110, 479-485. https://doi.org/10.1016/j.egypro.2017.03.172

Hrovatin, N., Dol Sak, N., \& Zori, J. (2016). Factors impacting investments in energy efficiency and clean technologies: Empirical evidence from Slovenian manufacturing firms. Journal of Cleaner Production, 127, 475-486. https://doi.org/10.1016/J.JCLEPRO.2016.04.039

IEA. (2010a). Benchmarking document, technology: Televisions. Retrieved from http://mappingandbenchmarking.iea4e.org/shared_files/393/download

IEA. (2010b). Energy efficiency governance handbook (2nd ed.). Retrieved from http://www.iea.org/publications/freepublications/publication/gov_handbook.pdf

IEA. (2013). Transition to sustainable buildings: Strategies and opportunities to 2050. Retrieved from https://www.iea.org/publications/freepublications/publication/ Building2013_free.pdf

IEA. (2015). Energy efficiency and behaviour in India. Retrieved from https://www.iea.org/media/workshops/2015/eeuevents/behave1103/S2India.pdf

International Energy Agency. (2010). Energy efficiency governance handbook. Paris: OECD/IEA.

International Energy Agency. (2014). Capturing the multiple benefits of energy efficiency. Retrieved from http://www.iea.org/termsandconditionsuseandcopyright/

Jairaj, B., Agarwal, A., Parthasarathy, T., \& Martin, S. (2016). Strengthening governance of India's appliance efficiency: Standards and Labelling program. Retrieved from https://www.wri.org/sites/default/files/Strengthening_Governance_of_Indias_Appliance_Efficiency_Standards_and_Labelling_Program.pdf

Jefferson, M. (2016). A global energy assessment. WIREs Energy and Environment, 5(1), 7-15. https://doi.org/10.1002/wene.179

Kalmykova, Y., Patrício, J., Rosado, L., \& Berg, P. E. (2015). Out with the old, out with the new - The effect of transitions in TVs and monitors technology on consumption and WEEE generation in Sweden 1996-2014. Waste Management, 46, 511-522. https://doi.org/10.1016/J.WASMAN.2015.08.034

Karekezi, S. (2002). Poverty and energy in Africa-A brief review. Energy Policy, 30(11-12), 915-919. https://doi.org/10.1016/S0301-4215(02)00047-2

Kumar, S. (2013). Global experience with energy efficiency and the role of the private sector. WIREs Energy and Environment, 2(3), 269-281. https://doi.org/10.1002/ wene. 51

Lefèvre, N., De T'serclaes, P., \& Waide, P. (2006). Diffusion: The case of compact fluorescent lamps. Retrieved from https://www.iea.org/publications/ freepublications/publication/Fluorescent.pdf

Lekov, A. B., Franco, V. H., Wong-Parodi, G., McMahon, J. E., \& Chan, P. (2010). Economics of residential gas furnaces and water heaters in US new construction market. Energy Efficiency, 3(3), 203-222. https://doi.org/10.1007/s12053-009-9061-y

Letschert, V., McNeil, M., Zhou, N. and Sathaye, J. (2009). Residential and transport energy use in India: Past trend and future outlook (January) 66. Retrieved from http://re.indiaenvironmentportal.org.in/files/LBNL-1753E.pdf

Letschert, V. E., Bojda, N., Ke, J., Mcneil, M. A., \& Lawrence, E. O. (2012). Estimate of cost-effective potential for minimum efficiency performance standards in 13 major world economies—Energy savings, environmental and financial impacts. Retrieved from https://ies.lbl.gov/sites/all/files/lbnl-5723e_pdf.pdf

Lohani, B. N., \& Azimi, A. M. (1992). Barriers to energy end-use efficiency. Energy Policy, 20(6), 533-545. https://doi.org/10.1016/0301-4215(92)90021-S

Maguire, J., Fang, X., \& Wilson, E. (2013). Comparison of advanced residential water heating technologies in the United States, Colorado. Retrieved from https://www. nrel.gov/docs/fy13osti/55475.pdf

Makridou, G. (2016). Energy efficiency assessment in European Union countries and industries. Chania: Technical University of Crete.

Malik, P. (2016). Spending patterns of Indian population. Journal of Business Management and Economics, 4(10), 1-3. https://doi.org/https://doi.org/10.15520/jbme. 2016.vol4.iss 10.223.pp01-03

Mandil, C. (2006). Light's labour's lost: Policies for energy-efficient lighting. Energy World, 1(343), 14-15.

Matsumoto, S. (2016). How do household characteristics affect appliance usage? Application of conditional demand analysis to Japanese household data. Energy Policy, 94, 214-223. https://doi.org/10.1016/J.ENPOL.2016.03.048

McNeil, M. A., Iyer, M., Meyers, S., Letschert, V. E., \& McMahon, J. E. (2005). Potential benefits from improved energy efficiency of key electrical products: The case of India. Environmental Energy Technologies Division Lawrence Berkeley National Laboratory Retrieved from https://www.osti.gov/scitech/servlets/purl/862333

McNeil, M. A., Iyer, M., Meyers, S., Letschert, V. E., \& McMahon, J. E. (2008). Potential benefits from improved energy efficiency of key electrical products: The case of India. Energy Policy, 36(9), 3467-3476. https://doi.org/10.1016/j.enpol.2008.05.020

Ministry of Power. (2015). All India energy statistics Retrieved from http://powermin.nic.in/sites/default/files/uploads/Annual_Report_2014-15_English.pdf

Ministry of Power. (2016). BEE announces new star rating methodology for air conditioners. Retrieved from http://pib.nic.in/newsite/PrintRelease.aspx?relid=149154

Mundaca, L., Neij, L., Worrell, E., \& McNeil, M. (2010). Evaluating energy efficiency policies with energy-economy models. Annual Review of Environment and Resources, 35(1), 305-344. https://doi.org/10.1146/annurev-environ-052810-164840

Murthy, K. V. N., Sumithra, G. D., \& Reddy, A. K. N. (2001). End-uses of electricity in households of Karnataka state, India. Energy for Sustainable Development, 5(3), 81-94. https://doi.org/10.1016/S0973-0826(08)60278-1

Nagesha, N., \& Balachandra, P. (2006). Barriers to energy efficiency in small industry clusters: Multi-criteria-based prioritization using the analytic hierarchy process. Energy, 31, 1969-1983. https://doi.org/10.1016/j.energy.2005.07.002

Nardelli, A., Deuschle, E., de Azevedo, L. D., Pessoa, J. L. N., \& Ghisi, E. (2017). Assessment of light emitting diodes technology for general lighting: A critical review. Renewable and Sustainable Energy Reviews, 75, 368-379. https://doi.org/10.1016/J.RSER.2016.11.002

National Electricity Conservation Program. (2017). Minimum performance standards and labelling to improve energy efficiency building energy efficiency leading the region. Retrieved from http://ccap.org/assets/CCAP-Booklet_Brazil.pdf

NEMA. (2014). Lighting supports environmental strategies in building and renovation. The Magazine of the Electroindustry, 19(2). Retrieved from https://www.nema. org/news/EI PDF/EI_Feb14.pdf.

Nemet, G. F. (2009). Demand-pull, technology-push, and government-led incentives for non-incremental technical change. Research Policy, 38(5), 700-709. https:// doi.org/10.1016/J.RESPOL.2009.01.004

NITI Aayog. (2016). India energy security scenarios 2047 user guide: Residential lighting and appliances. Retrieved from http://www.indiaenergy.gov.in/iess/docs/ Residential-Lighting_Appliances-documentation.pdf

Padmavathi, K., \& Daniel, S. A. (2011). Studies on installing solar water pumps in domestic urban sector. Sustainable Cities and Society, 1(3), 135-141. https://doi. org/10.1016/j.scs.2011.06.002

Parikh, K. S., \& Parikh, J. K. (2016). Realizing potential savings of energy and emissions from efficient household appliances in India. Energy Policy, 97, $102-111$. https://doi.org/10.1016/j.enpol.2016.07.005

Park, W. Y., Phadke, A., Shah, N., \& Letschert, V. (2011). TV energy consumption trends and energy-efficiency improvement options. Retrieved from https://ies.lbl. gov/sites/all/files/lbnl-5024e_1.pdf

Pereira, G. I., \& Da Silva, P. P. (2017). Energy efficiency governance in the EU-28: Analysis of institutional, human, financial, and political dimensions. Energy Efficiency, 10(5), 1279-1297. https://doi.org/10.1007/s12053-017-9520-9

Pérez-Lombard, L., Ortiz, J., \& Pout, C. (2008). A review on buildings energy consumption information. Energy and Buildings, 40(3), 394-398. https://doi.org/10. 1016/j.enbuild.2007.03.007 
Peters, M., Schneider, M., Griesshaber, T., \& Hoffmann, V. H. (2012). The impact of technology-push and demand-pull policies on technical change - Does the locus of policies matter? Research Policy, 41(8), 1296-1308. https://doi.org/10.1016/J.RESPOL.2012.02.004

Planning Commission Government of India. (2014). The final report of the expert group on low carbon strategies for inclusive growth. Retrieved from http:// planningcommission.nic.in/reports/genrep/rep_carbon2005.pdf

RAC. (2016). Room air conditioners. Department of Energy. Retrieved from https://energy.gov/energysaver/room-air-conditioners

Rasul, G., \& Sharma, B. (2016). The nexus approach to water-energy-food security: an option for adaptation to climate change. Climate Policy, 16(6), 682-702. https://doi.org/10.1080/14693062.2015.1029865

Rathi, S. S., Chunekar, A., \& Kadav, K. (2012). Appliance ownership in India: Evidence from NSSO household expenditure surveys 2004-05 and 2009-10 (Discussion Paper). India: Prayas Energy Group.

Reddy, A. K. N. (1991). Barriers to improvements in energy efficiency. Energy Policy, 19(10), 953-961. https://doi.org/10.1016/0301-4215(91)90115-5

Rogers, E. M. (1963). Diffusion of innovations (3rd ed.). Glencoe, Scotland: Free Press. https://teddykw2.files.wordpress.com/2012/07/everett-m-rogersdiffusion-of-innovations.pdf isbn:0-612-62843-4. Retrieved from.

Rohdin, P., \& Thollander, P. (2006). Barriers to and driving forces for energy efficiency in the non-energy intensive manufacturing industry in Sweden. Energy, 31(12), 1836-1844. https://doi.org/10.1016/J.ENERGY.2005.10.010

Ryan, L., \& Campbell, N. (2012). Spreading the net: The multiple benefits of energy efficiency improvements. Paris: International Energy Agency. https://doi.org/10. $1787 / 5 \mathrm{k} 9 \mathrm{crzjbpkkc-en}$

Schleich, J. (2004). Do energy audits help reduce barriers to energy efficiency? An empirical analysis for Germany. International Journal of Energy Technology and Policy, 2(3), 226. https://doi.org/10.1504/IJETP.2004.005155

Schleich, J. (2009). Barriers to energy efficiency: A comparison across the German commercial and services sector. Ecological Economics, 68(7), 2150-2159. https:// doi.org/10.1016/j.ecolecon.2009.02.008

Schleich, J., \& Gruber, E. (2008). Beyond case studies: Barriers to energy efficiency in commerce and the services sector. Energy Economics, 30(2), 449-464. https:// doi.org/10.1016/J.ENECO.2006.08.004

Shah, N., Park, W. Y., Bojda, N., McNeil, M. A., \& Waide, P. (2014). Superefficient refrigerators: Opportunities and challenges for efficiency improvement globally. Paper presented at 2014 ACEEE Summer Study on Energy Efficiency in Buildings. Retrieved from https://aceee.org/files/proceedings/2014/data/papers/8-1072.pdf

Singh, D., Sant, G., \& Chunekar, A. (2010). Ceiling fan the overlooked appliance in energy efficiency discussions. Pune, India: Prayas Energy Group. Retrieved from. http://www.prayaspune.org/peg/media/k2/attachments/ceiling_fans_the_overlooked_appliance_107A01.pdf

Singh, D., Sant, G., \& Chunekar, A. (2012). Improving energy efficiency in India: Need for a targeted and tailored strategy. WIREs Energy and Environment, 1(3), 298-307. https://doi.org/10.1002/wene.45

Singh, V. K., Martins, A. G., \& Henriques, C. (2016). Energy savings technical potential of energy efficient appliances in India's residential sector. Paper presented at CYTEF 2016 - VIII Iberian Congress, VI Ibero-American Refrigeration Sciences and Technologies, Coimbra, Portugal, May 3-6, 2016.

Sorrell, S. (2004). The economics of energy efficiency: Barriers to cost-effective investment. England: Edward Elgar.

Sorrell, S. (2015). Reducing energy demand: A review of issues, challenges and approaches. Renewable and Sustainable Energy Reviews, 47, 74-82. https://doi.org/10. 1016/j.rser.2015.03.002

SSEF. (2012). Market research of agriculture pump-sets industry of India. Retrieved from http://shaktifoundation.in/wp-content/uploads/2014/02/Agriculture-PumpStudy_Report-Final_12th-June.pdf

Steve Nadel. (1994). Minimum efficiency standards—Options for state and federal action. Washington, DC. Retrieved from: American Council for an Energy Efficient Economy. http://aceee.org/research-report/a941

Sundarmoorthy, S., \& Walia, A. (2017). India's experience in implementing strategic schemes to enhance appliance energy efficiency \& futuristic integrated policy approaches to adopt most efficient technologies. Paper presented at ECEEE Summer Study Proceedings. Retrieved from https://www.eceee.org/library/conference_ proceedings/eceee_Summer_Studies/2017/2-policy-governance-design-implementation-and-evaluation-challenges/india8217s-experience-in-implementing-strategicschemes-to-enhance-appliance-energy-efficiency-futuristic-in

TERI. (2006). National energy map for India: Technology vision 2. Office of the Principal Scientific Advisor, Government of India. India: A TERI Publication.

TERI. (2014). TERI environment data directory yearbook. India: A TERI Publication.

Thomas, S., Tholen, L., Rasch, J., \& Hafiz, A. (2015). Energy efficiency policies for appliances. Retrieved from http://www.efficiency-from-germany.info/ENEFF/ Redaktion/EN/Downloads/Publikationen/eneff-policies-for-appliances.pdf?_blob=publicationFile\&v=2

Trianni, A., Cagno, E., Thollander, P., \& Backlund, S. (2013). Barriers to industrial energy efficiency in foundries: A European comparison. Journal of Cleaner Production, 40, 161-176. https://doi.org/10.1016/J.JCLEPRO.2012.08.040

U.S. Department of Energy. (2013). Conventional storage water heater basics. Department of Energy. Retrieved from https://energy.gov/eere/energybasics/articles/ conventional-storage-water-heater-basics

UNFCCC. (2010). UNFCCC ehandbook-Startpage. Retrieved from http://bigpicture.unfccc.int/

Vaidya, P., Vasudevan, R., \& Cherail, K. (1996). Transforming the building energy efficiency market in India: Lessons from the USA. ACEEE. Retrieved from http:// aceee.org/files/proceedings/2010/data/papers/2029.pdf

Wan, T., Dou, Y., Wang, L., Yang, L., Zhou, X., Wan, D., \& Hu, J. (2011). Environmental benefits for phase-out HCFC-22 in the residential air-conditioner sector in China. Advances in Climate Change Research, 2(2), 86-92. https://doi.org/10.3724/SP.J.1248.2011.00086

World Bank. (2008). Residential consumption of electricity in India documentation of data and methodology India: Strategies for low carbon growth draft. Retrieved from http://www.moef.nic.in/downloads/public-information/Residentialpowerconsumption.pdf

How to cite this article: Singh VK, Henriques CO, Martins AG. Assessment of energy-efficient appliances: A review of the technologies and policies in India's residential sector. WIREs Energy Environ. 2018;e330. https://doi.org/10. 1002/wene.330 